\title{
Erken Dönem Hadis Çalışmalarında Şiîlik İthamları -Hadis Tarihi Çerçevesinde Bir İnceleme-
}

\author{
Accusations of Shi'ism in Early Hadith Studies \\ -An Analysis from the Framework of History of Hadith-
}

\section{Muhammed Enes TOPGÜL*}

Öz: Şî̉nın bir mezhep olarak ortaya çıkışından önceki bir dönemde Ehl-i hadîs âlimleri tarafından kaleme alınan ricâl türü eserlerde bazı râvilerin Şiî düşüncelerle ilişkilendirildikleri görülür. Hicrî ilk üç asırdaki Şîilik ithamları doğal olarak bir mezhebe mensubiyeti değil, bir düşünme ve inanç tarzına yakınlığı ifade eder. Bu yakınlık genellikle Hz. Ali’nin savaşlarındaki haklılığı ve muhaliflerinin haksızlığına inanmak ve bunu açıkça dile getirmek, Şiî cemaat yapılarıyla içli dışlı olmak, ashâb hakkında eleştiride bulunmak ya da onları tezyif etmek, Hz. Ali ya da Ehl-i beyt'in fezâili veya sahâbenin mesâlib/ meâyibi hakkındaki rivayetleri derlemek ya da nakletmek, Hz. Ali’nin Hz. Osman’a ya da Hz. Ebû Bekir veya Hz. Ömer’e üstünlügüne inanmak, Şî̂ temelli isyanlara fiilen katılmak ya da bu isyanları meşru görmek, Şiî cemaatlerce benimsenen bazı ayırıcı itikadî veya fikhî görüşleri kabul etmek gibi farklı alanlarda gözlemlenebilir. Klasik dönem tarih, tabakât, terâcim, ricâl eserleri tarandığında 207 Kütüb-i Sitte râvisinin farklı lafızlarla Şiî düşüncelere mensup olmakla itham edildiği görülmektedir. Râvilerin ve râvilerin Şiî olup olmadıklarının tespiti için belli yöntemler öneren bu makale ilgili râvi grubu üzerinden şu dört temel soruya birtakım cevaplar verilebileceğini iddia etmektedir: 1Sünnî ve Şiî ders halkalarının ayrışma tarihi, 2- Sünnî-Şiî rivayet geçişkenliklerinin dönemi, 3- Ehl-i bid'at'ten hadis rivayeti, 4- Cerh-tadîlin icra edilme tarzı. İlk sorunun cevabı müttehem râvilerin dönemleri, coğrafyaları ve Şiî eğilimlerinin oranı çerçevesinde verilir. Gerek müttehem gerekse farklı oranlarda Şiî eğilimler taşıyan râvilerin dönemleri Sünnî-Şî̂ ders halkalarının ayrışma zamanın hicrî 3. asrın başları olduğunu ortaya koyar. Bunun öncesinde ise Şiî eğilimli râviler her iki ekolün ders halkalarına girip çıkmaktaydılar. İkinci olarak Sünnî-Şiî rivayet geçişkenliğinin büyük oranda 2./8. asırda ve Şiî eğilimli râviler eliyle temin edildiği anlaşılmaktadır. Üçüncü olarak Ehl-i bid'at'ten hadis rivayeti hakkında klasik hadis usûlü kaynaklarında çizilen teori ile pratik durum arasında ciddi farklılıkların olduğu açıktır. Zira Kütüb-i Sitte'de Şiî eğilimli onlarca râvinin bulunması muhaddislerin erken devir üsluplarının etraflıca alınması gerektiğini gösterir. Makalenin son iddiası ise erken dönem cerh-ta'dîl pratiğinin genel kabullerin aksine neredeyse her zaman rivayet edilen metinler üzerinden işletildiğidir. Râvinin zabtının tespitinde zaten muâraza/mukâbele dışındaki yöntemler nadiren kullanılırken bu makale râvinin adaletinin tespitinde de rivayetlerin etkili olabileceğini teorik olarak iddia etmektedir. Bu noktada ileri sürülen argüman ise münekkitler ile râviler arasında birebir görüşme imkanının çoğu zaman olmayışıdır. Cerh-ta‘dîl bilgisinin hoca-talebe ilişkisi ile alınmış olma ihtimali veya râvi hakkındaki ithamların münekkitler arasında

Arş. Gör. Dr., Marmara Üniversitesi İlahiyat Fakültesi Hadis Anabilim Dalı, enes.topgul@marmara.edu.tr Orcid No: 0000-0003-3077-2610 
yaygın olarak bilindiği gibi kabuller ise tam olarak dışlanmasa da hem ispatlanmalarının zorluğu hem de oran olarak çok olmamaları nedeniyle makul bulunmamıştır. İlgili râvi grubunun güvenilirlik durumları veya etnik kökenleri de burada tartışma konusu yapılmıştır ve bu konular üzerinden bazı yargılara varılmıştır. Makalenin nihai hedefi ise ricâl kitaplarındaki statik bilgilerin hadis tarihi açısından nasıl anlamlı kılınabileceğini göstermektedir. Zira bu tarz bir arayış ancak ilgili kitaplara yönelik tematik yaklaşımlarla mümkündür. Nitekim burada yapılmaya çalışıldığı üzere belli bir tema etrafında anılan râvilerin durumlarının farklı açılardan tahlil edilmesi sadece o râvilere ilişkin çıkarımlar yapılmasına değil hadis tarihinin kapalı kalan dönemleri ve tartışma konularına dair de birtakım fikirler yürütülmesine imkan verecektir.

Anahtar Kelimeler: Şîa, Şî̂, Şiîlik İthamı, Ehl-i hadîs, münekkit, cerh-ta'dîl

Abstract: This article argues that it has been clearly observed that some transmitters have been associated with Shī ìte thoughts in rijāl type works written by Ahl al-hadith scholars prior to the formation of the Shī'a as a sect. Naturally, Shī ite accusations during the first three centuries after the hijrah denotes a proximity to a thinking and a belief form, and not an affiliation to a certain sect. This proximity generally can be observed as believing in 'Alī b. Abī Tālib's legitimacy and his opponents' illegitimacy in his wars and the expressing of this openly in society, being close to Shì'ite circles, criticizing or insulting the other companions of the Prophet, compiling and narrating traditions about the virtues ( $\left.f a d \bar{a}^{\prime} i l\right)$ of 'Alì b. Abì Tàlib or Ahl al-bayt, or the defects and the faults (mathälib/ma 'áyib) of the companions of the Prophet, believing in the preference and priority of 'Alī over 'Uthmān, Abū Bakr and 'Umar, participating in Shī'îte revolts or considering these as legitimate, and accepting distinctive theological or jurisprudential opinions. If one glances over classical history, țabaqāt and rijāl books, it is clear that 207 of al-Kutub al-Sitta narrators are accused of having Shī ìte views, albeit with different wordings. In this article certain methods are followed in order to examine these transmitters and to ascertain whether they are Shī' ite or not. Ultimately, the present article claims that following four essential questions whereby this issue can be answered through certain transmitter categorization: 1- What was the time of Sunnī and Shī ite hadith circles' separation, 2- What was the period of the traditions' transition from Ahl al-sunna to the Shī'a, 3- What was the problem of narration from Ahl al-bid 'a, and 4what is the execution type of jarh-ta' $d i l$.

The first question's answer is provided by the framework of those transmitters' historical periods, geographical context and the extent of their tendency towards the Shi a views. The historical periods of both the accused transmitters and the other transmitters show them having different extent of tendencies toward the Shì a and this reveals that dissociation of Sunnite-Shī îte course circles can be dated to the beginnings of the $3^{\text {rd }} / 9^{\text {th }}$ century. Before this historical period, transmitters with Shī ìte tendencies seem to have been following both schools' circles. The response to the second inquiry is that it is understood that the narrative transitivity among Sunnite and Shī îte was mostly elicited by transmitters with Shi'i ite tendencies in the $2^{\text {nd }} / 8^{\text {th }}$ century. The third question's response is that it is obvious that there are crucial differences between theory and practice regarding the hadith narration from the Ahl al-bid ' $a$ that are drawn from classical usūl al-hadith sources. Yet, the fact that there are tens of transmitters with Shì' ite tendencies in al-Kutub al-Sitta indicates that the early style of the transmitters must be dealt with attentively and thoughtfully. The last claim of this paper is that early jarhta 'dil practices are undertaken via texts which are almost always narrated, contrary to general acceptance. 
This article tentatively asserts that the narrations can be influential to examine the fairness of the transmitter. The argument at this point is that most of the time there is no possibility of a meeting personally among transmitters and critics (munaqqid) to have taken place. Possibility of acquiring knowledge of jarh-ta' $d \bar{l} l$ via disciple-master relationship or recognitions that accusations over transmitter are widespread among critics are not considered as reasonable due to the difficulty of proving them and the scarcity of their quantity. The reliability position or ethnic background of the subject transmitters are also discussed here and some conclusions are attained. The ultimate goal of the article is to demonstrate how the static information in the rijäl books can be useful in terms of the history of hadith. Since, such a research can be possible only through thematic approaches, hence the attempt in this article to examine the status of the above mentioned transmitters from different angles and viewpoints around a certain theme will not just pave way for possible interpretations regarding those transmitters but open the ways for some new opinions on the above discussed topics and the reveal some of the obscure periods of the history of hadith.

Keywords: Shī'a, Shī '̀ Shī 'ìte accusation, Ahl al-hadìth, critics, jarh-ta 'dìl.

\section{Giriş}

Münekkit kimliği ile öne çıkan Ehl-i hadîs bilginlerince kaleme alınan tarih, tabakât ve ricâl türü eserlerde, bazı hadis râvilerinin Ehl-i hadîs dışı fırkalara mensup olmakla itham edildikleri görülür. Söz konusu ithamların ortaya çıkışını icbar eden sosyal, siyasî ve ilmî şartların etraflıca tespit edilmesi hem kendine özgü bir grup olarak Ehl-i hadîs'in kimlik bulma süreci hem de cerh-ta'dîl ilminin sistemleşme dönemi hakkında birtakım yargılara varma imkanı verebilir. Konu daha dar bir çerçevede ele alındığında ise bu eserlerde bazı râvilerin Şiî düşüncelerle ilişkilendirildikleri dikkat çeker. Bu makale hicrî ilk üç asırdaki Şiîlik ithamlarının mahiyeti, itham edilen râvilerin dönemleri, coğrafyaları, etnik kimlikleri, güvenilirlik durumları, münekkitlerin dönemleri ve ithamlarda kullandıkları lafızlar gibi hususlara dair panoramik bir sunum yaparak Şiîlikle itham edilen ya da farklı oranlarda Şî̂ eğilimler taşıdığı yargısına varılan râviler üzerinden dört temel soruya cevap aramayı hedeflemektedir: 1- Sünnî ve Şiî ders halkalarının ayrışma tarihi, 2- Sünnî halkalardaki rivayetlerin Şiî halkalara geçiş dönemi, 3- Ehl-i bid'at'ten hadis rivayeti, 4-Cerh-ta'dîlin icra edilme tarzı. Kanaatimizce ilgili râvi grubu, hem Sünnî-Şiî ilim halkalarının ayrışma tarihi ve rivayet geçişkenliklerinin dönemi, dolayısıyla Şiảnın mezhepleşme süreci hem hicrî 2. asır Ehl-i hadîs'inin râvinin adaleti bağlamında gündeme aldığı iki temel meseleden biri olan Ehl-i bid'at'ten hadis rivayeti (diğeri yalancılık) etrafındaki tartışmalar hem de münekkitlerin bir râviyi tenkit etme süreçleri hakkında bir veri olarak kullanılabilir. Son tahlilde burada örnek bir râvi grubuna uygulanan çalışma tarzının ricâl metinlerinin hadis tarihi bakımından nasıl işlevsel kılınabileceğine dair bir örnek olması umulmaktadır.

Çalışmaya esas teşkil eden Şiîlikle müttehem râvi kümesinin tespitinde ve ilgili râvilerin Şiî düşüncelere sahip olup olmadıkları hakkında yargıya varma sürecinde izlenen metot hakkında birtakım ön bilgilerin verilmesi uygun olacaktır. Şiîlikle itham edilen râvileri tespit 
etmek için öncelikle hem kapsayıcılık iddiası hem de kısmen muhtasar tabiatı dikkate alınarak geç dönem ricâl metinlerinden İbn Hacer el-Askalânînin (ö. 852/1449) Tehzîbü’t-Teh$z \hat{\imath} b$ 'i baştan sona taranmış, böylece konu bir yandan Kütüb-i Sitte ricâli ile kayıtlanırken diğer yandan ithamlarda kullanılan anahtar kelime ve kavramlar tespit edilmiştir. Ardından Şiî, yeteşeyye‘u, müteşeyyi', fîhi teşeyyu', yeglû fi’t-teşeyyu', Râfizî, fîhi rafz, Sebeî, Gâlî, Muhtârî, Haşebî, Alevî vb. kavram ve kelimeler tarih, tabakât ve ricâl literatüründe taranmış ve böylece Şiîlikle itham edilen râvilerin mümkün mertebe eksiksiz bir dökümünün yapılması temin edilmiştir. Klasik eserlerde yapılan taramaların ardından doğrudan veya dolaylı olarak Şiî eğilimli râviler hakkında yargılar serdeden, listeler veren klasik ve modern Sünnî ve Şiî literatür imkan ölçüsünde gözden geçirilmiştir. Sonuç olarak Kütüb-i Sitte’de rivayetlerine yer verilen 207 râvinin farklı lafızlarla Şî̂lik ithamına maruz kaldığı belirlenmiştir.

Makalenin ana veri altyapısını temin eden bir diğer çalışmamdaki ${ }^{1}$ pek çok bilgi ve yorum burada ya tashih edilerek kullanılmış ya da bu çalışma açısından işlevsiz olduğu için hiç dikkate alınmamıştır. Orada, zaman darlığı nedeniyle durumlarının hadis tarihi bakımından tahliline teşebbüs edilemeyen 201 râvi tespit edilebilmişken, 8 sene boyunca yapılan ekstra okumalar sonucunda bu râvilerden bazıları devre dışı bırakılmış, on kadar râvi ana kümeye dahil edilmiştir. O çalışmada tespit edemediğim veya o tarihten sonra kaleme alınan bazı çalışmalardaki veriler de burada gündeme alınmıştır. Örneğin Ebû Abdullah İbnü’l-Vezîr elYemânînin (ö. 840/1436) el-Avâsım ve’l-kavâsım adlı eserinin ilgili kısmı, ${ }^{2}$ Hüseyin Azîzî, Pervez Rüstegâr ve Yusuf Bayât tarafından Râviyân-i müşterek: pejûheşî der bâzşinâsî-i râviyân-i müşterek-i Şîa ve Ehl-i sünne adıla yayınlanan ${ }^{3}$ ve biraz özetle er-Ruvâtüll-müşterekûn beyne'ş-Şîa ve's-Sünne adıyla Arapçaya çevrilen eser, ${ }^{4}$ Michael Dann'in Contested Boundaries: The Reception of Shī ite Narrators in the Sunnī Hadith Tradition adlı doktora tezi ${ }^{5}$ bu aşamada incelenmiştir. İlk iki metin râvi isimleri ve güvenilirlikleri hakkında genel nitelikli birtakım bilgiler verirken Dann'in çalışması hem tespit ettiği râvi kümesini farklı açılardan tahlil etmesi ${ }^{6}$ hem de bu râvilerden gelen rivayetleri dikkate alması bakımından onlardan ayrilmaktadır.

Bu makalede, yukarıda zikredilen çalışmaların aksine Şî̀ eğilimli râviler taranırken konu Kütüb-i Sitte râvileriyle kayıtlanmasına rağmen, tarama lafızlarının fazla oluşu ve teknik imkanlardan yararlanıldığı için ithama maruz kalan daha fazla râvi tespit edilmiştir. Diğer

1 Muhammed Enes Topgül, Hadis Râvilerinde Şî̀lik Eğilimi (yüksek lisans tezi, 2010), Marmara Üniversitesi Sosyal Bilimler Enstitüsü.

2 Muhammed b. İbrahim İbnü'l-Vezîr el-Yemânî, el-Avâstm ve'l-kavâsım fi'z-zeb an sünneti Ebi'l-Kâsım (nşr. Şuayb el-Arnaût), I-IX, Beyrut: Müessessetürr-Risâle, 1412/1992, II, 394 vd.

3 Kum: Bustân-i Kitâb, 1380.

42 cilt, Tahran: el-Mecma'u'l-Âlemî li'l-Takrîb beyne'l-Mezâhibi'l-İslâmiyye, 1430/2009.

5 Princeton University, 2015.

6 Dann, çalışmasının ilk bölümünde bu araştırmada olduğu gibi râvilerin coğrafya ve dönemlerine yoğunlaşmıştır (s. 34-63). Ancak o, râviler hakkında ithamların doğru olup olmadığı meselesini gündemine almadığı gibi bu makalede konu edilen Sünnî ve Şiî ders halkalarının ayrışma tarihi, Sünnî-Şiî̀ rivayet geçişkenliklerinin dönemi ve cerh-tácîlin icra edilme tarzına da temas etmemektedir. 
çalışmalarda gözetilmeyen Kütüb-i Sitte kaydı dikkate alınmadı̆̆ı takdirde râvi sayısının 3040 civarında artması mümkünse de, söz konusu ilave râvilerin burada, hadis ve mezhepler tarihine dair varılan yargıları yanlışlamayacağı öngörülmektedir.

İkinci olarak râvilerin farklı düzeylerde Şiîlik eğilimi taşıdıklarına dair yargılara nasıl varıldığı izah edilmelidir. Zira tespit edilen 207 râvinin Şiîlik düzeyleri, "aşırı Şiî eğilimli”, "Şiî eğilimli" ve "Şiîlik eğilimleri az olan" râviler şeklinde üç kısımda incelenmiştir. Eğer birden fazla Ehl-i hadîs âlimi bir râvinin Şiî eğilimlerinden söz ediyor ve bu itham erken dönem Şiî ricâl eserlerince doğrulanıyorsa ilgili râvinin geniş anlamıyla Şiî eğilimli olduğu kabul edilmiştir. Şiî ricâl eserlerinin bir kriter olarak belirlenmesinde ise hem bazı klasik âlimlerin bir râvinin Şiîlik eğiliminden bahsederken onun Şiî ricâl eserlerinde yer aldığına işaret etmeleri ${ }^{7}$ hem de Cemâleddin el-Kâsımînin (ö. 1332/1914) şu izahı etkili olmuştur:

Cerh-ta'dîl âlimleri eserlerinde, bid'atçi olmakla itham edilen pek çok kimseye yer vermişlerdir. Onların bu konudaki dayanakları, bu râvilerden herhangi birinin Şiî, Hâricî, Nâsıbî gibi ifadelerle nitelenmesidir. Ancak bu kişiler hakkında söylenenler gelişigüzel birer ifade ve iftira olabilir. Sahîhayn râvilerinden olup Şiî eğilimlere sahip olmakla itham edilen pek çok râvinin aslında Şîa tarafından bilinmemesi buna işaret eder. Şîanın ricâl kitaplarından Keş̧̧î [ö. 4./10. asrın ilk yarısı] ve Necâşînin [ö. 450/1058] eserlerine başvurdum. Ancak Süyûtînin [ö. 911/1505] Takrîb [şerhi Tedrîbürr-râvi]'de kendinden önceki âlimlere dayanarak Şiî eğilimlere sahip olmakla itham ettiği ve Buhârî [ö. 256/870] ile Müslim'in [ö. 261/875] eserlerinde rivayetlerine yer verdiği 25 râviden sadece 2'sini bu eserlerde görebildim; onlar da Ebân b. Tağlib [ö. 140/757] ve Abdülmelik b. Áyen'dir [ö. 2/8. asrın ilk çeyreği]. Diğer râviler hakkında ise bu iki kitapta herhangi bir bilgiye rastlayamadım. Böylece önemli bir bilgi ve güzel bir faydayı elde etmiş olduk: bid'atçilikle itham edilen râviler hakkında, o [mezhebin] ricâl musannefâtına başvurmanın gerekliliğii. Bu şekilde ithamın doğrusu yanlışı ortaya çıkar... ${ }^{8}$

Kâsımînnin, erken dönem Şiî̀ ricâl eserlerinin tüm Şiî râvileri mümkün mertebe kapsadığı ön kabulüne dayanan ve tarafımızca da benimsenen bu izahı ve klasik bazı bilginlerin tatbikatları Şiî ricâl kaynaklarına râvilerin Şiî eğilimlerini tespit için başvurulabileceğini gösteriyorsa da, tek başına Şîi kaynaklara gitmek râvinin Şiîlik seviyesi hakkında çok fazla şey söylemez. Râvilerin Şiîlik eğilimleri üç başlık altında incelenirken eğer râvi Sünnî literatürde "aşırı Şî̂, Râfizî, Gâlî, sahâbeye hakaret ederdi, recate inanırdı" gibi aşırılığa delâlet eden lafızlarla suçlanıyor ve Şiî ricâl eserleri de ilgili râviye ileri düzeyde önem atfediyorsa râvinin "aşırı Şiî" olduğu yargısına varılmıştır. Râvi hakkında Sünnî eserler "Şiî,, Şiîlik eğilimi vardı" gibi tasvirler yapmış ve Şiî eserler de râviye imâmların ashâbı içerisinde yer vermişse ilgili râvi "Şiî eğilimli”" olarak nitelenmiştir. Eğer Sünnî eserlerdeki ithamlar sadece bir

7 Örneğin İbn Hacer, Bessâm b. Abdullah’n biyografisine yer verirken İbn Ukde (ö. 322/933), Necâşî ve Tûsînin onu Şiî ricâl arasında zikrettiklerini belirtir (Ahmed b. Ali İbn Hacer es-Askalânî, Tehzîbü’t-Tehzîb [nşr. Halîl Me’mûn Şîha - Ömer Selâmî - Ali b. Mes'ûd], I-VI, Beyrut: Dâru'l-Ma'rife, 1416/1996, I, 333). İbn Hacer’in özellikle Lisânü'lMîzân'da Şiî ricâl eserlerini kullanma biçimi ilgi çekici bir araştırma konusu olup yakın zamanda tarafımızdan ele alınması hedeflenmektedir.

8 Muhammed Cemâleddin el-Kâsımî, Kavâidü't-tahdîs min funûni mustalahi'l-hadîs (nşr. Muhammed Behcet elBaytâr). Dımaşk: Mektebü’n-Neşri'l-Arabî, 1343/1925, s. 177. 
iki münekkitten aşırıllğa delâlet etmeyen lafızlarla geliyor, râvinin tafdîl tartı̧̧malarında taraf olması ya da Hz. Alinnin savaşlarındaki haklılı̆̆ını benimsemesi söz konusu ediliyor ya da mutedil münekkitler râvinin Şiîlik eğiliminin azlığından bahsediyorsa, öte yandan sadece Tûsînin (ö. 460/1067) Ricâli gibi sınırlı sayıda Şiî ricâl eseri râviye yer vermişse ilgili râvinin Şî̂lik eğilimlerinin az olduğu kabul edilmiştir.

Son olarak Sünnî kaynaklarda herhangi bir râvinin herhangi bir düzeyde Şiî eğilimler taşıdığına dair ifadeler yer almasına rağmen erken dönem Şiî ricâl eserleri ilgili râviyi imâmların ashâbı içerisinde zikretmiyorsa, muahhar eserler ${ }^{9}$ râviyi Şiî kabul etse de, söz konusu ithamda gerçeklik payının olmadığ 1 düşünülmüștür. Bu durumda "O halde ilgili râvi neden tenkit edildi?” sorusu gündeme gelir ki, kanaatimizce durumu böyle olan râviler sadece birtakım haberlerin râvisi oldukları için töhmet altında kalmışlardır. ${ }^{10}$ Eğer erken devir Sünnî cerh-taddîl kaynaklarında râvinin Şiîliğinden bahsedilmezken, Sâcî (ö. 307/919), Nedîm (ö. 385/995[?]), Şehristânî (ö. 548/1153), Ziriklî (ö. 1976) gibi yargıları kanaat oluşturmayacak münekkitler ya da muahhar müellifler bir râviyi Şiîlikle itham etmişlerse ve râvi Şiî eserlerce anılmışsa ya da râvi hakkında erken dönem münekkitlerinden bir veya ikisi Şiîlik ithamında bulunmuş ancak râvinin durumu Şiî ricâl eserlerinde tartışmalı ise net bir yargıya varılamamış ve râvi hakkında tevakkuf edilmiştir. Durumu böyle olan râvilerin sayısı sadece 4'tür.

İlgili râvi kümesi hakkındaki istatistik verilere geçmeden önce Şiîlik ithamlarının sebeplerine özetle temas etmek gereklidir. Hicrî ilk üç asırda Şiî eğilimlerinden bahsedilen bir râvinin mezhebî anlamda Şiî olamayacağı açıktır. Zira İmâmî-Şiî düşüncenin, imâmet, ismet, takıyye gibi farklı unsurları bir araya getiren bir ana yapı olarak tesisi ancak hicrî 4 . asrın başlarında söz konusu olmuştur. Bundan dolayı ilk üç asırda bu tarz ithamlara maruz kalan râviler, her ne kadar Şiî kimliğin bazı unsurlarını taşısalar da İmâmiyye’yi kastedecek şekilde mutlak olarak Şiî diye anılamazlar. Bu tarz râvilerin itham edilmelerine mesnet teşkil eden düşünce ve tavırlar incelendiğinde onların "Şiî eğilimli" olarak nitelenmeleri daha isabetli görünmektedir. Kanaatimizce söz konusu râvilerin ithamındaki temel etkenler şunlardır: Hz. Ali’nin savaşlarındaki haklılığı, muhaliflerinin haksızlığına inanmak ve bunu açıkça dile getirmek, Şiî cemaat yapılarıyla içli dışlı olmak, ashâb hakkında eleştiride bulunmak ya da onları tezyif etmek, Hz. Ali ya da Ehl-i beyt'in fezâili veya sahâbenin mesâlib/meâyibi hakkındaki rivayetleri derlemek ya da nakletmek, Hz. Ali’nin Hz. Osman’a ya da Hz. Ebû Bekir veya Hz. Ömer’e üstünlüğüne inanmak, Şiî temelli isyanlara

9 Buradaki "erken dönem" ifadesiyle Berkî, Keşŝ̂, Tûsî ve Necâşînin eserleri, "muahhar eserler" tabiriyle ise genel olarak hicrî 5. asırdan sonra kaleme alınan, özellikle de Sünnî literatürdeki ithamlar üzerinden râvinin Şiîliğini göstermeye çalışan çağdaş "Ricâl" türü eserler kastedilmektedir.

10 Tamamlanma aşamasında olan bir kitap çalışmamızda Sünnî kaynaklarda ağır Şiîlik ithamlarına maruz kalmalarına rağmen Şiî ricâl eserlerinde kendilerine yer verilmeyen bir râvi kümesinin rivayetleri etraflıca tahlil edilmiş ve söz konusu ithamların Hz. Ali ve Ehl-i beyt' in fezâili ya da bazı sahâbîlerin meâyibi hakkındaki zayıf ve ferd rivayetlerden kaynaklandığı tespit edilmiştir. Bu durum aynı çalışmada bir râvinin adalet bakımından tenkidinde, onun naklettiği rivayetlerin ileri düzeyde etkili olduğu tezinin ileri sürülmesinin de mesnedini teşkil etmiştir. 
fiilen katılmak ya da bu isyanları meşru görmek, Şiî cemaatlerce benimsenen bazı ayırıcı itikadî veya fikhî görüşleri kabul etmek. Bu tavırların en az birini taşıyan râviler klasik literatürde farklı lafızlarla nitelenmişlerdir. Anlaşıldığı kadarıyla ithamlarda kullanılan lafızların kullanılış biçimi ve dönemi pek çok açıdan râvinin durumuna ışık tutar ki bu konu ileride ele alınacaktır.

\section{Müttehem Râvilerin Dönemleri}

207 kişilik Şîilikle müttehem râvi kümesi ilk olarak dönemleri açısından tahlil edilecektir. Zira ithamların tarihî seyri hem Ehl-i hadîs'in hem de onlar tarafından tesis edilen cerhta‘dîl ilminin gelişimi hakkında bilgi verebilir. İthamların yoğunlaştığı dönemin söyleyebileceği diğer bazı hususlar ise Sünnî-Şiî ilim halkalarının ayrışma tarihi ve Sünnî-Şiî rivayet geçişlerinin yoğun olduğu dönemlerdir. Aşağıdaki tabloda Şîilikle müttehem râviler vefat dönemleri dikkate alınarak 25’er senelik periyotlarla sunulmuştur.

Grafik 1. Müttehem Râvilerin Dönemleri

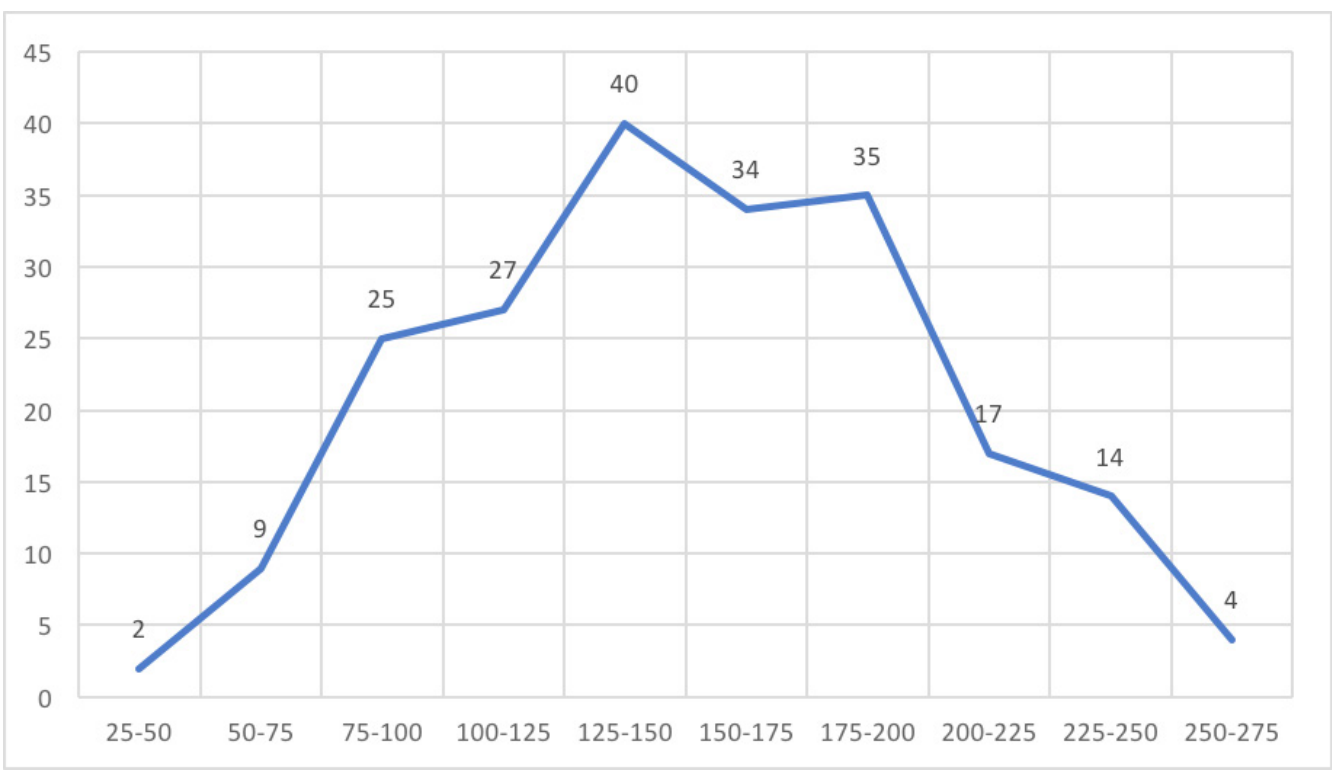

Tablodan takip edilebileceği üzere vefatları hicrî 25-75 seneleri arasına denk gelen râvi sayısı sadece 11'dir. Büyük oranda sahâbenin hayatta olduğu bu dönemde Şîilik gibi bir düşünceden bahsetmek mümkün olmayıp söz konusu râvilerin itham edilmeleri, Hz. Ali'nin yanında ya da Ehl-i beyt temelli hareketlerde yer almış olmalarından kaynaklanır. Bu isimlerden bazıları Emevîleri hedef alan belli isyanları örgütlemiş, bazıları ise Hz. Osman karşıtlığ1 
ile de tanınmışlardır. Bu isimlerden l'i aşırı Şiî eğilimli, 2’si Şiî eğilimli, 5’i de Şiî eğilimleri az olan kimseler olarak nitelenmiştir. 3 kişi hakkındaki ithamlar ise Sünnî kaynakların geneli ve Şiî eserlerce doğrulanmamıştır. Hicrî 75-125 seneleri arasına gelindiğinde Şiîlik ithamına maruz kalan 52 râvinin olduğu görülür. Rakamdaki sayısal yükseliş hem hadis naklinde sistemli olmasa da rol alan râvi sayısının artışı hem de Şî̂ cemaatlerin belli isimler etrafında toplanmasından kaynaklanmıştır. Hicrî 75-100 seneleri arasında vefat eden 25 râviden 2'si aşırı Şiî eğilimli, 2'si Şiî eğilimli, 8'i de Şiî eğilimleri hafif olan kimselerdir. 13 râvi hakkındaki ithamlar ise doğrulanmamıştır. Hicrî 100-125 seneleri arasında ise 4 râvinin aşırı Şiî eğilimli, 5 râvinin Şiî eğilimli, 3 râvinin ise az düzeyde Şiî eğilimli olduğu görülür. Bu dönemde vefat eden 13 râvi Şiî değilken, 2 râvi hakkında ise net bir yargıya varılamamıştır.

Tablodaki dikkat çekici bir veri ise hicrî 125-150 seneleri arasında vefat eden müttehem râvilerin sayısındaki artıştır. Söz konusu 40 râvinin 3'ünün aşırı Şiî, 9'unun Şiî, 8'inin ise az düzeyde Şiî eğilimler taşıdığı tespit edilmiştir. 18 râvi hakkındaki ithamlar kaynaklarca doğrulanmazken, 2 râvi hakkında tevakkuf edilmiştir. Bu tarihi aralıktaki sayısal artış öncelikle Ehl-i hadîs ve Şiî cemaatlerin kimlik kazanma sürecine girdiklerini gösterir. Zira artık Ehl-i hadîs âlimleri "kendilerinden olmayan" râvilere karşı daha temkinlidirler. Aynı tarihi aralıkta cerh-ta'dîl ilminin de sistemleşmeye başladığı dikkate alındığında, bu dönemde Ehl-i hadîs âlimlerinin kendi ana çizgilerini ister sahip oldukları birtakım inanışlarla isterse naklettikleri haberlerle zorlayan kimselerin tespitine bu dönemde önem verildiği söylenebilir. Söz konusu zaman aralığına Şiî cemaatlerin gelişim seyri açısından bakıldığında ise, ilgili tarihî aralığın büyük oranda mutedil Şiî cemaati sıradan bir cemaat yapısı olmaktan çıkarıp daha sistemli bir işleyişe kavuşturan Cáfer es-Sâdık’’n (ö. 148/765) imâmlı̆̆ı sürecine tekabül ettiği görülür. Nitekim bu dönemde yaşayıp farklı oranlarda Şiî eğilimlere sahip olduğu tespit edilen isimlerin neredeyse tamamının Şiî kaynaklarda Sâdık'ın ashâbı içerisinde zikredilmiş olmaları da dikkat çekicidir. ${ }^{11}$ Bu dönemdeki ithamlar genellikle ashâb hakkında olumsuz kanaatler arz etmek ve tafdîl tartışmaları etrafında seyreder. Muhtemelen belli konulardaki rivayetlerin nakli de ilgili râvilerin itham edilmelerinde etkili olmuştur.

Vefatları hicrî 150 ile 200 seneleri arasına tekabül eden toplam 69 müttehem râvi vardır. Hicrî 150-175 arasında vefat eden 34 râviden l'inin aşırı Şîî, 8'inin Şiî̀, 7'sinin ise az düzeyde Şî̀ eğilimler taşıdığı tespit edilmiştir. 18 râvi hakkındaki ithamlar ise Sünnî kaynakların geneli ve Şiî ricâl eserlerince doğrulanmamıştır. Hicrî 175-200 arasında vefat eden 35 râviden ise 1'inin aşırı Şiî, 4'ünün Şiî, 5’inin ise hafif düzeyde Şiî eğilimler taşıdığı belirlenmiştir. 25 râvi hakkındaki ithamlar ise Şiî kaynaklarca doğrulanmaz. Bu dönemde hem aşırı Şiî eğilimli râvilerin hem de diğer düzeylerdeki Şiî eğilimli râvilerin sayısında, hicrî

11 Tabii ki burada Sâdık’n ashâbı içerisindeki ciddi bir grubun onun babası Muhammed el-Bâkır’ın da yakın ashâbından olduğunu hatırlatmakta fayda vardır. Lalani’nin tasvirleri Bâkır’n çevresindeki isimler ve o dönemki Şiî cemaat hakkında yeterince bilgi vericidir (bk. Arzina R. Lalani, Early Shīīi Thought: The Teachings of Imam Muhammad al-Bāqir, London: I.B. Taurus, 2000, özellikle s. 96 vd.). 
100-150 senelerine göre düşüş yaşanmıştır. Öte yandan Şiîlikle itham edildikleri halde haklarındaki ithamlar doğrulanmayan râvilerin sayısındaki artış dikkat çekicidir. Bu durum söz konusu râvileri tenkit eden ve büyük oranda hicrî 3. asrın ilk çeyreğinde yaşayan Ehl-i hadîs âlimlerinin farklı gerekçelerle daha fazla sayıda râviyi Şiî düşüncelerle özdeşleştirdikleri yani muhalif fırkalara karşı daha fazla teyakkuzda oldukları anlamına gelir ki söz konusu dönem Ehl-i hadîs'in mihne sorunu ile yüzleștiği ve devletin Şiî cemaatlerle yakınlaştığı bir tarihi aralığa tekabül etmektedir. İlgili tabloda veriler Sünnî-Şiî ilim halkalarının ayrışma süreci için hicrî 2 . asrın son çeyreğinin yakından incelenmesi gerektiğini de göstermektedir. Zira hicrî 125 ile 200 seneleri arasında Şiî eğilimli râvilerin sayısında gözlemlenen nisbî düşüş Şiî cemaatlerin gitgide kendilerine özgü halkalara daha fazla öncelik tanıdıklarını gösterebilir. Söz konusu dönemdeki ithamların da büyük oranda sahâbe ve özellikle Hz. Osman hakkında olumsuz kanaatler arz etmek ve tafdîl tartışmalarında Hz. Ali'yi öncelemekle ilgili olduğu görülür. Yine mesâlib ve fezâil rivayetleri de ithamlarda etkili olmuştur.

Öte yandan hicrî 125-200 seneleri arası Şîilikle müttehem ve Şiî eğilimli râvilerin sayısal fazlalığı Sünnî-Şiî rivayet geçişkenliklerinin de büyük oranda bu dönemde yaşandığını göstermektedir. Zira Şiî eğilimli râvilerin Ehl-i hadîse mensup hocalarından aldıkları haberleri Şiî halkalara taşıdıkları benzer rivayetlerin her iki ekolün kaynaklarında da aynı râvilerce rivayet edilmesinden anlaşılmaktadır. Ancak ilginç bir şekilde Şiî eserlerdeki rivayetler büyük oranda sıradan râvilere değil, imâmlara nispet edilmektedir. Dolayısıyla geçişkenliği temin eden râvilerin, haberleri sahâbe üzerinden Hz. Peygamber'e değil imâmlara nispet eden Şî̂ rivayet düşüncesi üzerinde de hayli etkili olduğunu düşünmek mümkündür. Rivayet geçişkenliğini tespit için takip edilebilecek bir diğer metot ise Sünnî ve Şiî kaynaklarda aynîlik arz eden rivayetlerin Şiî isnâdlarında yer alan râvilerin hoca ağlarını Sünnî ricâl kaynaklarında takip etmek olabilir. Kanaatimizce büyük oranda olmasa da rivayetleri Şiî halkalara taşıyan Şiî isnâdlardaki isimler Sünnî kaynaklarda Şiîlik ithamına maruz kalan râvi kümesi ile örtüşecektir. Hicrî 3. asrın başlarından itibaren ise her iki ekolün kaynaklarında da kendisine yer verilen ortak râvi sayısı oldukça minimal bir düzeye inecektir.

Hicrî 200-225 seneleri arasına gelindiğinde Şiîlikle müttehem 17 râvinin varlığı dikkat çeker. Bu râvilerden sadece 1'inin gerçekte Şiî eğilimli olması, geriye kalan 16 râvinin ise Şiî düşüncelerle herhangi bir düzeyde ilişkilendirilememesi hayli ilginçtir. Bu tablonun Me’mûn dönemi (198-218/813-833) ile Ehl-i beyte yönelik devlet politikalarının farklılaşması ile ilişkilendirilmesi mümkünse de, kanaatimizce daha kabul edilebilir açıklama artık Şiî cemaat yapıları ile irtibatlı isimlerin büyük oranda Sünnî hadis halkalarından çekilip kendi özel halkalarında ilim yapmaya başlamalarıdır. Bu yargı erken dönem Şiî rivayet tarihi bakımından hayli önemli bir isim olan Muhammed b. Ebî Umeyr'den (ö. 217/832) gelen bir ifadeyle de örtüşmektedir. Rivayeti nakleden Fazl b. Şâzân en-Neysâbûrî (ö. 260/874) şöyle der: 
Babam, Muhammed b. Ebî Umeyr'e "Sünnî âlimlerle karşılaştın. Nasıl oldu da onlardan hadis işitmedin?” diye sorunca İbn Ebî Umeyr şu cevabı verdi: “Onlardan hadis dinlemiştim. Ancak ashâbımızdan pek çoğunun hem âmme’den [Sünnîler] hem de hâssa'dan [Şiîler] ilim aldıklarını ve âmme’nin hadisini hâssa'dan, hâssảnın hadisini âmme'den rivâyet edecek şekilde bunları birbirine karıştırdıklarını gördüm. Ben de karıştırmaktan çekindim ve onlardan dinlemeyi/rivâyeti terk edip söz konusu tavra yöneldim. ${ }^{12}$

İbn Ebî Umeyr' in ifadesi, ilgili tavrın tarihini net olarak belirlemeye imkan vermiyorsa da, onun hicrî 217 senesinde vefat etmiş olması, Şiî halkalardaki bilgilerle yetinme bilincinin en geç hicrî 3. asrın başlarında merkez Şiî cemaatte yerleştiğini gösterebilir. Onun hareket tarzının diğer Şiî ilim taliplerince de çok geçmeden benimsendiği hem ilgili dönemde Sünnî kaynaklarda Şiîlikle müttehem râvilerin sayısındaki ciddi düşüşle hem de sonrasında hicrî 225-275 seneleri arasındaki Şî̂likle müttehem râvilerin sayıca azlığıyla doğrulanmaktadır. Zira söz konusu dönemde 18 râvi itham edilmişse de, bu râvilerden sadece 1'inin aşırı Şiî, 3 'ünün Şiî eğilimli olduğu tespit edilebilmiştir. Geriye kalan râviler hakkındaki ithamlar ise kaynaklarca doğrulanmamaktadır. Halkaların ayrıştığını gösteren diğer bazı delillere de burada yer verilebilir. Bu delillerin bir diğeri, erken Şîi ricâl literatüründe özellikle hicrî 150 senesinden önce imâmların ashâbı içerisinde sayılan isimlerin Sünnî literatürde az da olsa tespit edilebilmesine mukabil, bu tarihten sonra Şiî literatürde anılan râvilerin bilinirlik oranının Sünnî eserlerde gitgide azalmasıdır. İkinci bir delil Şî̂ isnâd yapılarının hicrî 200 öncesi ile sonrası arasındaki yapısal farklılıklarıdır. Erken Şî̂ rivayet literatüründe Sünnî râvilerin isimleri isnâdlarda geçmesine rağmen hicrî 3. asrın başlarından itibaren bilgi akışı sadece Şiî râvilerle temin edilmiş ve rivayetler neredeyse her zaman imâmlara nispet edilmiştir. Üçüncü delil ise rivayet metinlerindeki tasarrufların ve bağlam inşalarının tarihidir. Zira erken literatürde Şiî düşünceyi destekleme yönü zayıf olan veya Şiî düşünceye karşıtlık arz eden bazı haberler süreç içerisinde ziyade ve eksiklikler gibi birtakım tasarruflarla kabul edilebilir hale getirilmiş ya da rivayetlerin bağlamlarında Şiî düşünceyi tahkim etmeye matuf tasarruflara gidilmiştir. ${ }^{13}$ Başka bir açıdan bakıldığında söz konusu üç delil, rivayet geçişkenliklerinin de büyük oranda hicrî 2 . asırda başlayıp 3. asrın başlarına kadar devam ettiğini göstermektedir. ${ }^{14}$ Bu noktada Şiî eğilimli 83 râvinin dönemlerini gösteren ve büyük oranda bir önceki grafikle örtüşen bir grafiğinin sunulması faydalı olacaktır.

12 Muhammed b. Ömer el-Keşş̂, İhtiyâru Márifeti’r-ricâl (nşr. Hasan el-Mustafavî), Meşhed: Dânişkâh-i Meşhed, 1348hş./1969, s. 591.

13 Şiî isnâd yapılarının Keşşînin Márife’si özelinde bir tahlili için bk. Muhammed Enes Topgül, Erken Dönem Şiî Ricâl İlmi: Keş̧̧ิ Örneği, İstanbul: İFAV, 2015, s. 206-284. Tasarruflu rivayet olgusu ve dönemlerine dair bazı örnekler için bk. Bekir Kuzudişli, Şîa ve Hadis: Başlangıcından Kütüb-i Erbaa’ya Hadis Rivayeti ve İsnad, İstanbul: Klasik, 2017, özellikle asıllara tahsis edilen kısım, s. 225-305.

14 Rivayet geçişkenlikleri meselesi belli rivayetler özelinde Bekir Kuzudişli tarafından çalışılmış ve hicrî 2. asırda ve 4. asrın ilk çeyreğinde geçişlerin olduğu tespit edilmiştir (bk. "Sunnī-Shī'î Interaction in the Early Period: The Transition of the Chains of Ahl al-sunna to the Shī' a", Ilahiyat Studies, 2015, VI, sy. 1, s. 7-45). 
Grafik 2. Şiî Eğilimli Râvilerin Dönemleri

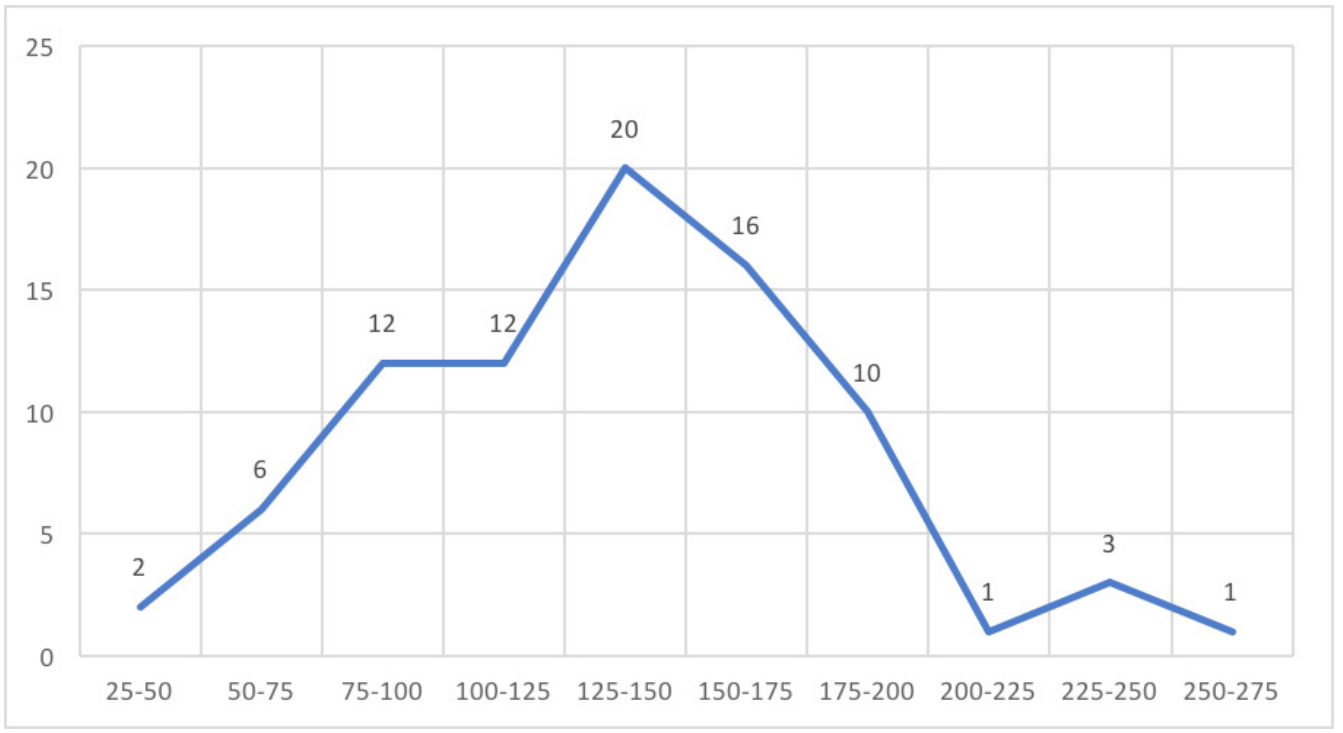

Öte yandan ilk grafikteki veriler hicrî 2. asırda Ehl-i hadîs halkalarında bid'at fırkalarla ilişkilendirilen pek çok ismin yer aldığını göstermektedir ki aşağıda müttehem râvilerin rivayetlerine hangi müelliflerin yer verdiği, bu râvilerin güvenilirlik durumları ve kendilerini itham eden münekkitlerin hangi dönemde yaşadıkları incelenirken de bu husus vurgulanacaktır. Ancak her halükarda Şî̂likle müttehem râviler hakkındaki bu tespitin diğer fırkalara ne oranda teşmil edilebileceği ayrıca incelenmelidir.

\section{Müttehem Râvilerin Coğrafya ve Kabileleri}

Şî̂likle müttehem râvilerin coğrafyaları hakkında yapılacak tespitler hem mezhebi yapıların gelişim sürecinde belli şehirlerin etkili olup olmadı̆̆ı hem de herhangi bir şehirde yaşıyor olmanın töhmet altında kalmaya sebep olup olmayacağı hakkında fikir verebilir. Sünnî eserlerde Şiî eğilimlere sahip oldukları gerekçesiyle eleştirilen râvilerin coğrafyaları aşağıdaki grafikte sunulmuştur. 
Grafik 3. Müttehem Râvilerin Coğrafyaları

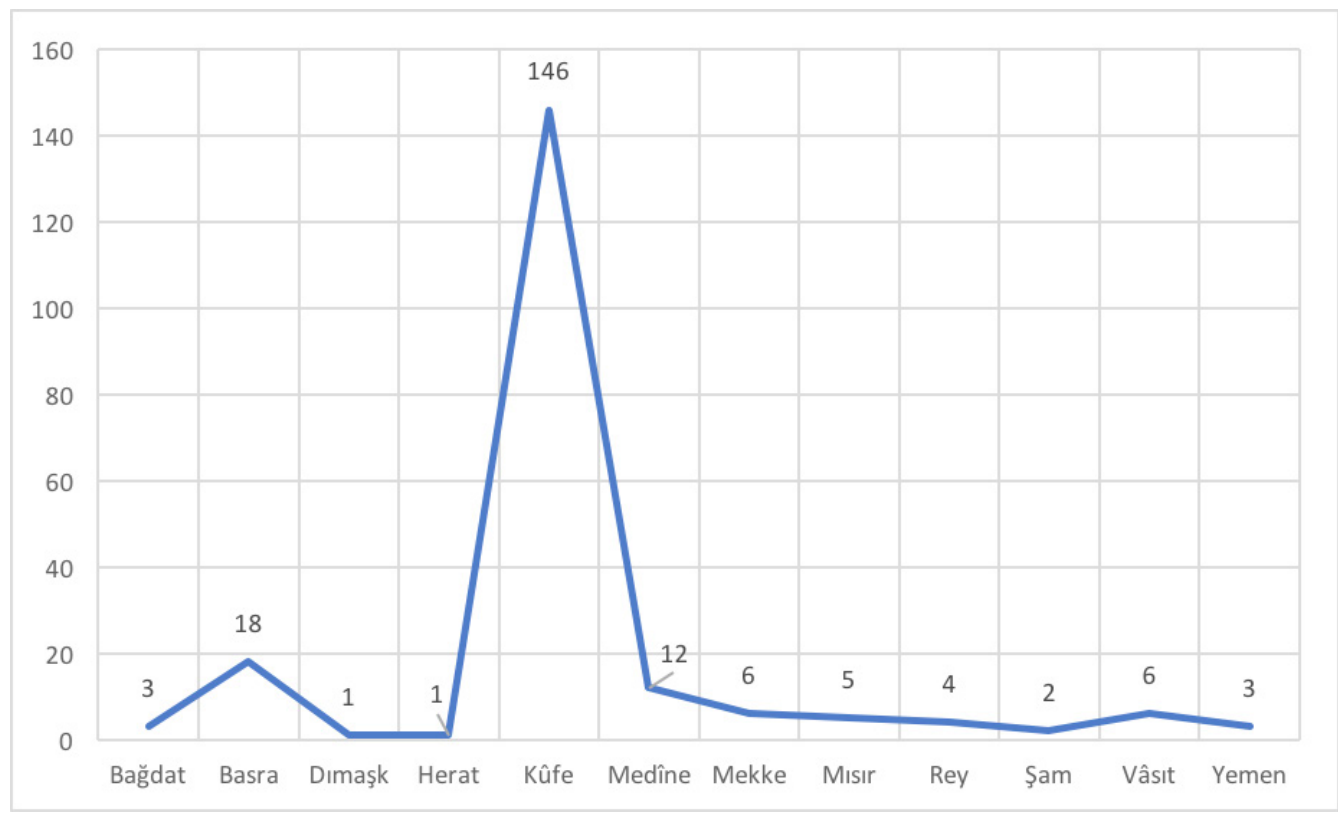

Müttehem 207 Kütüb-i Sitte râvisinin 146'sının klasik kaynaklarda el-Kûfî nisbesiyle anıldığı yani ömrünün büyük bir kısmını ya da bu nisbeyle anılmasını temin edecek kadar bir süreyi Kûfe'de geçirdiği tespit edilmiştir. Bu veri gerek klasik gerekse modern literatürde Kûfe’nin Şiî düşüncenin ilk müntesiplerinin merkezi olduğu yönündeki yargılarla örtüşmektedir. ${ }^{15} \mathrm{~Hz}$. Ali'nin başkenti olan ve Emevî ve Abbâsî dönemlerinde Şiî temelli isyanlara büyük oranda ev sahipliği yapan Kûfe şehri, Kum ve Bağdat öncesinde yani İmâmî-Şiîliğin sistemleşmesi öncesinde Şî̂ cemaatlerin merkeziydi. Bir sonraki grafikten anlaşılacağı üzere hicrî 200'lerden sonra Kûfeli Şiî râvilerin oranındaki düşüş, ders halkalarının ayrışması sonucundaki sayısal azalmanın yanı sıra bu tarihten sonra Kum şehrinin önem kazanmasından da kaynaklanıyor olsa gerektir. ${ }^{16}$ Müttehem râvilerin Kûfe dışında Basra (18) ve Medine (12) ile irtibatlı oldukları görülür. Diğer şehirlerdeki müttehem râvilerin oranı ise herhangi bir ekstra yorum yapmaya imkan verecek boyutta değildir. Hicrî 2 . asrın en etkili ilim merkezlerinin Kûfe ve Basra olduğu, Medine'nin ise ilk asırdaki dinamizmini muhafaza edemediği bilinmektedir. Bununla birlikte Basra'da müttehem râvi sayısı 18 iken, Şî̂ eğilimli râvi sayısının sadece 3 oluşu, bu şehrin Şiî düşüncelerden ziyade

15 Klasik anlatılara bazı örnekler için bk. Muhammed Enes Topgül, "Bir Cerh Sebebi Olarak Teşeyyu' (Şiîlik Eğilimi) Kavramına Tarihsel Bir Bakış”, Marmara Üniversitesi İlahiyat Fakültesi Dergisi, 2012, sy. 42, s. 53-6; Kûfe’nin Şiî bilincin oluşumu açısından önemi için bk. Najam Haider, The Origins of the Shī a: Identity, Ritual, and Sacred Space in Eighth-Century Küfa, Cambridge: Cambridge University Press, 2011.

16 Kum'un Şiî düşünce açısından önemini tarihi olarak görmek için bk. Andrew Newman, The Formative Period of Twelver Shī'ism: Hadith as Discourse Between Qum and Baghdad, Richmond: Curzon, 2000, s. 32 vd. 
Kaderî düşünce ekollerine ev sahipliği yaptığı yönündeki genel yargılarla örtüşmektedir. Medîne'deki râviler ise büyük oranda imâmlarla irtibatları dolayısıyla töhmet altında kalmış olmalıdırlar. Müttehem râvilerin coğrafi konumları böyleyken Şiî eğilimli râvilerin durumları Kûfe konusundaki yargıları iyice kuvvetlendirmektedir. Nitekim ilgili râvilerin vefat dönemlerine göre beldeleri şöyledir:

Grafik 4. Şiî Eğilimli Râvilerin Coğrafyaları

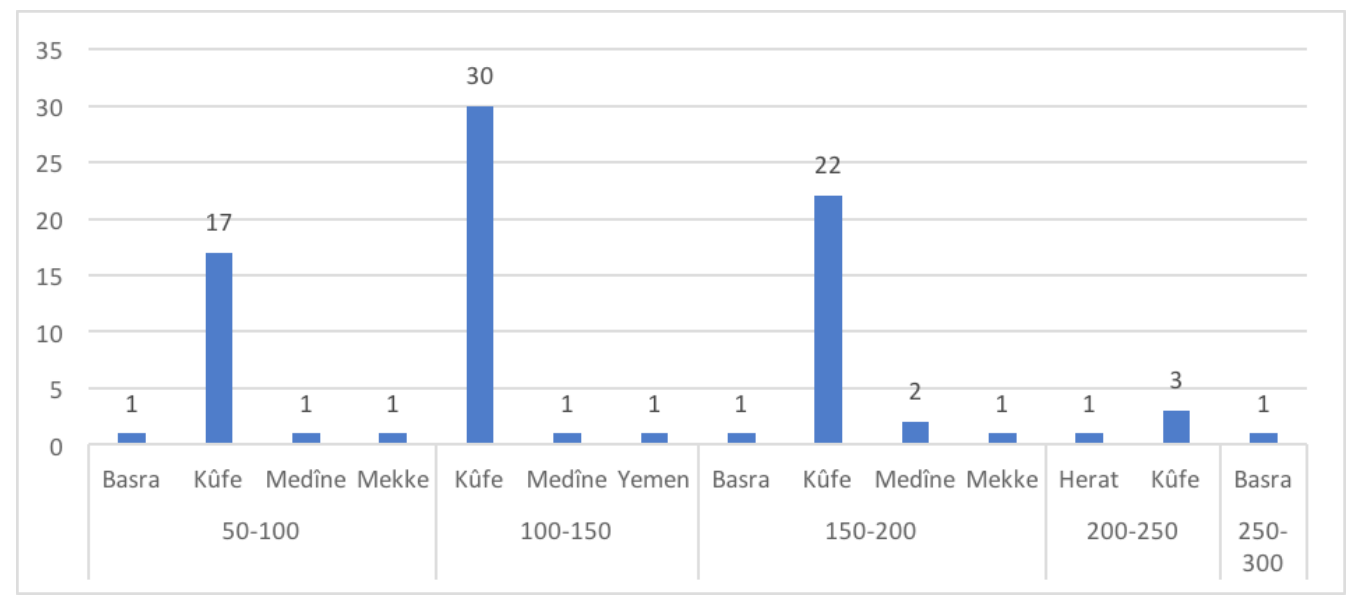

Bu tablodan anlaşılacağı üzere farklı oranlarda Şiîlik eğilimi taşıyan 83 râvinin 72'si Kûfe ile ilişkilidir. Şîlilk ithamına maruz kalan Kûfeli râvi sayısı 146 iken ithamların ancak yaklaşık \%50 oranında doğrulanabilmesi, Ehl-i hadîs bilginlerinin Kûfeli râvileri Şiî düşüncelere nispet etme konusundaki genel eğilimlerinin varlığını göstermekle birlikte teşhiste çok da isabetli olmadıklarını gösterir. Söz konusu tablo neredeyse 150 sene boyunca Kûfe’nin Şiî düşünce açısından vazgeçilmez olduğunu ispatlamaktadır. Öte yandan bu veriler Cáfer es-Sâdık ve sonrasındaki imamların ikametgahları ile Şiî cemaatlerin yayılım gösterdiği coğrafyanın mutlak olarak örtüşmediği anlamına gelir. Zira Sâdık hayatının tamamını Medine’de geçirmiş, ${ }^{17}$ Musa el-Kâzım (ö. 183/799) ömrünün sonlarına doğru Bağdat’a getirilmeden önce Medine’de yaşamış, Ali er-Rıza (ö. 203/818) Medine'de ikamet etmiş ve ancak yine halifenin daveti üzerine ömrünün sonlarında Merv’e gitmiştir. Erken dönemden itibaren Şî̂ cemaatin işlerinin bölgesel sorumlular (sefîr, vekîl) tarafından yürütülmesinin ${ }^{18}$ en muhtemel sebebi de imâmlar ile cemaatin arasındaki bu coğrafi uzaklık olsa gerektir.

17 Bununla birlikte onun Kûfe'ye gittiği ve hatta bir süre Irak bölgesinde yaşadığı rivayet edilir. Ayrıca Tûsînin Ricâl'i çerçevesinde yapılan bir sayıma göre ashâbının \%80'inden fazlası da Kûfelidir (konu hakkındaki bu muhtasar bilgiler ve Sâdık’ın konumu için bk. Ron P. Buckley, "Ja'far al-Sādiq as a Source of Shīī Traditions”, The Islamic Quarterly, 1999, XLIII, sy. 1, s. 37-58. [Makale Türkçe’ye tercüme edilmiştir, bk. "Şiî Hadislerin Kaynağı Olarak Cafer es-Sâdık”, Şî’nın Hadis Anlayışı Üzerine İncelemeler \{der. ve trc. M. Macit Karagözoğlu - M. Enes Topgül\} İstanbul 2015, s. 41-65]). 
Bu başlık altında son olarak Şiî eğilimli râvilerin kabilelerine ilişkin veriler incelenerek herhangi bir kabile mensubu olmakla Şiî eğilim taşımak arasında ilgi bulunup bulunmadığı tartışılacaktır. Şiî eğilimli râvilerin Temîm Oğulları (8), Esed Oğulları (7) ve Hemdân Oğulları (7) kabilelerine mensubiyet oranları diğer kabilelerden fazladır. Bu üç ana kabilenin ardından ise Abs Oğulları (3) ve Leys Oğulları (3) gelmektedir. Diğer kabile mensubiyetlerinin oranı ise dikkate alınamayacak derecede düşüktür. Bu kabileler içerisinde özellikle Hemdân Oğulları ve Esed Oğulları’nın erken dönemden beri Hz. Ali ve Ehl-i beyt ile irtibatlı oldukları ve Şiî temelli isyanlara destek verdikleri kaydedilir. ${ }^{19}$ Dolayısıyla Şiî eğilimli râvi kümesi çerçevesinde varılan sonuçların tarihi verilerle örtüştüğü söylenebilir.

\section{Müttehem Râvilerin Güvenilirlik Durumları}

Kütüb-i Sitte ricâlinden olup farklı lafızlarla Şiî düşüncelere sahip olmakla itham edilen 207 râvinin durumlarının cerh-ta‘dîl bakımından tahlil edilmesi, muhaddislerin Ehl-i bid’at ithamı ile güvenilirlik arasında mutlak anlamda karşıtlık görüp görmediklerini çözümleme imkanı verebilir. Acaba onlar sadece Şiî eğilimli ya da Şî̂likle müttehem oldukları gerekçesiyle ilgili râvilerin zayıf olduklarına $\mathrm{m} ı$ hükmediyorlardı yoksa hadis ilminde ehliyet sahibi olmayı yani hadisi aldığı gibi sonraki tabakalara aktarabilmeyi mi ilgili râvinin rivayetlerinin kabulü için yeterli görüyorlardı? Burada öncelikle Şiî eğilimler taşıdıkları gerekçesiyle itham edilen râvilerin güvenilirlik durumuna temas edilecektir. Ancak öncesinde grafiğe yansıtılan dört kategori yani "sika, sadûk, zayıf ve mechûl" sınıflandırması hakkında kısa bilgiler verilmelidir. Râvilerin güvenilirlik durumları hakkındaki yargılara varılırken genellikle İbn Sadd (ö. 230/845), Yahya b. Maîn (ö. 233/848) ve Ahmed b. Hanbel (ö. 241/855) gibi erken dönem münekkitlerin değerlendirmeleri esas alınmıştır. Ancak özellikle râvi hakkındaki görüşler uzlaştırılamaz derecede farklılık arz ettiğinde -ki bu durum oldukça nadirdir- Zehebî (ö. 748/1348) ve İbn Hacer gibi geç âlimlerin değerlendirmelerine bakılmıştır. Öte yandan sadûk kategorisine giren çoğu râvinin, bu niteleme erken münekkitlerden geldiğinde sika kategorisine, geç münekkitlerden geldiğinde ise zayıf râvi kategorisine daha yakın olduklarını hatırlatmakta da fayda vardır. Ancak çalışmanın ana konusu olmadığı için bu ayrım grafiğe yansıtılmamıştır.

Savory-Dionisius A. Agius), Toronto 1984, s. 183-206. (Makale Türkçe’ye tercüme edilmiştir, bk. "Şiî Fakihlerin İlk Dönemdeki Rolünün Anlaşılmasında Keşşînnin Ricâl'inin Önemi”, Şîa’nın Hadis Anlayışı Üzerine İncelemeler [der. ve trc. M. Macit Karagözoğlu-M. Enes Topgül], İstanbul 2015, s. 67-89). 
Grafik 5. Müttehem Râvilerin Güvenilirlik Durumları-1

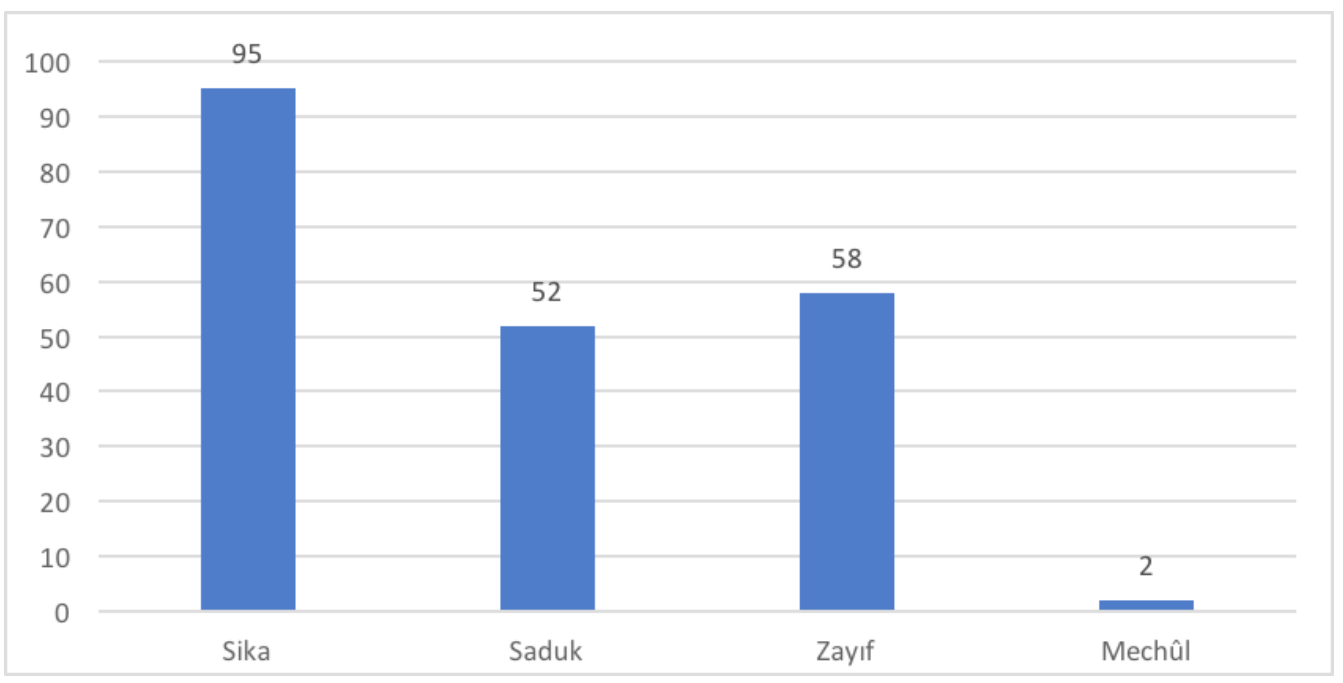

Şî̂likle müttehem 207 râviden 95’i (\%46) grafikte görüldüğü üzere sika olarak değerlendirilmiştir. Bu durum Şî̂lik ithamı ile zayıf kabul edilme arasında mutlak bir ilginin olmadığg anlamına gelmektedir. Müesses usûl benimsendiğinde sadûk statüsündeki 52 râvinin (\%25) de muhaddislerce dikkate alındığı rahatlıkla söylenebilir ki bu durumda rivayetleri doğrudan dikkate alınan ve muhtemelen türlü alanlarda delil olarak kullanılan râvilerin oranı \%71'e çıkmaktadır. Zayıf râvilerin sayısı ise 58'dir (\%28). Özellikle hicrî 2. asırda herhangi bir râvinin itikâdî olarak veya zabt açısından zayıflı̆̆ının onun rivayetlerini almaya engel olmadığ 1 ve bu dönemde naklettiği ya da derlediği rivayetlerde sadece sika râvilerden gelen rivayetleri dikkate almayı prensip olarak benimseyen muhaddislerin bir elin parmaklarını geçmediği bilinmektedir. Zira zayıf rivayet, hadis hakkında yargıya varırken hadisin tüm tariklerinin toplanmasını gerekli gören ilmî gelenekten dolayı ya da taşıdığı ekstra bilgi, diğer tariklerle kuvvetlenmesi gibi gerekçelerle muhaddisler tarafından daima kullanılagelmiştir. Kaldı ki hicrî 2. asır boyunca ve 3. asrın başlarında asl olan rivayetleri derleyip belli konulara göre tasnif etmek olduğundan bu tür râvilerin rivayetlerinin göz ardı edilmesi mümkün değildi. Hicrî 3. asrın ikinci çeyreğinden itibaren ise daha özel nitelikleri taşıyan râvilerin rivayetleri dikkate alındı ve sıhhat düşüncesinin yanı sıra amele ve fetvaya konu olma gibi ek kriterler de rivayet kabulünde etkili oldu. Kütüb-i Sitte’yi doğuran şartları dikkate almaksızın bu eserlerdeki uygulamaları merkeze koyan geç dönem muhaddisleri ise hem önceki literatürde hem de farklı gerekçelere istinaden Kütüb-i Sitte'de Ehl-i bid'at ile irtibatlı olan kimselerin rivayetlerine yer verilmesini bir problem olarak gördüler. Bu düşünce biçimi bir yandan bid'atın çerçevesinin daha net olarak belirlenmesini diğer yandan bid'atle müttehem isimlerin aslında bid'atçı olmadıklarını ispatlama sonucunu doğurdu. ${ }^{20}$ Halbuki erken dö- 
nem muhaddisleri için râvinin herhangi bir bid'atle maruf olması ya da itham edilmesi veya hadis ilmine ehliyeti bakımından zayıf kabul edilmesi, onun rivayetinin re'sen terk edileceği anlamına gelmemektedir. Kütüb-i Sitte'de ve özellikle sıhhat düşüncesini teliflerinin merkezine yerleştiren Buhârî ve Müslim’in eserlerinde bid'atçı ve zayıf pek çok râvinin rivayetine, farklı gerekçelerle yer verilmesi de bu hususa işaret etmektedir. Müttehem râvilerin güvenilirlik oranlarını ve hangi Kütüb-i Sitte müelliflerinin onların rivayetlerine yer verdiğini gösteren grafikler şöyledir:

Grafik 6. Müttehem Râvilerin Kütüb-i Sitte'deki Durumları ${ }^{21}$

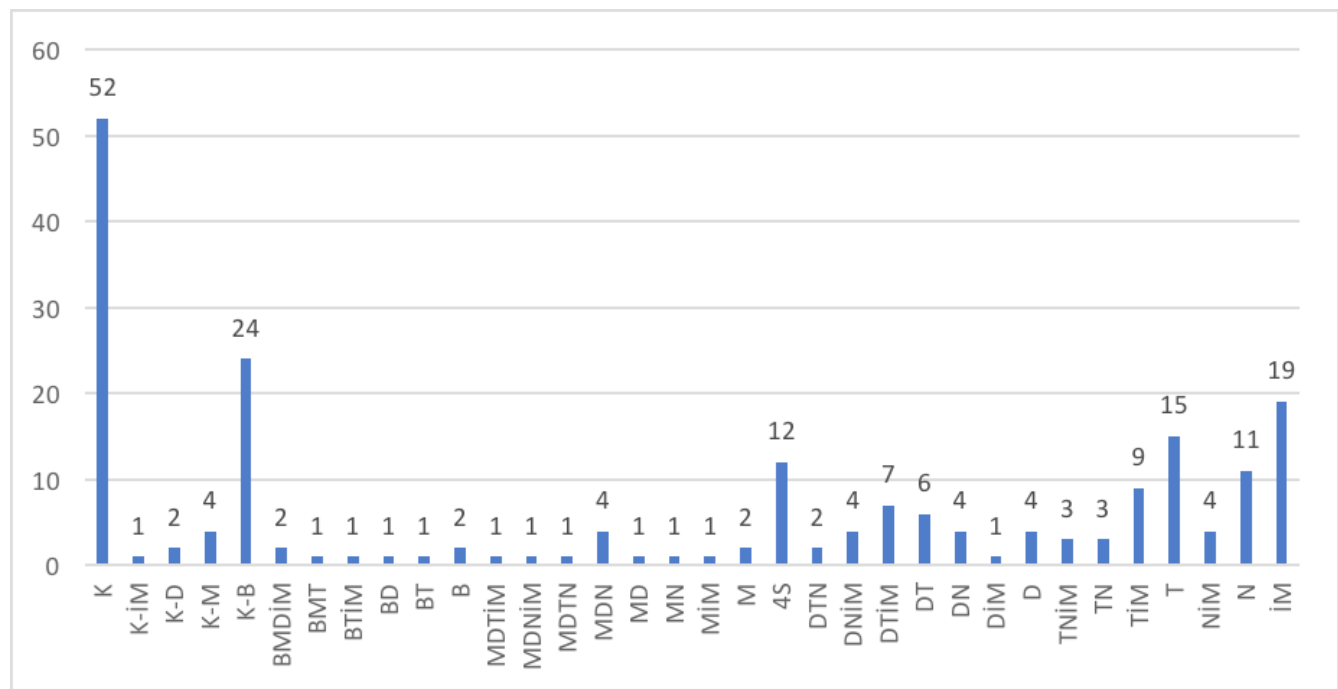

Grafikten takip edilebileceği üzere 207 râviden 52'sinin rivayetleri farklı oranlarda da olsa Kütüb-i Sitte müelliflerince dikkate alınmıştır. Buhârî ile Müslim’i sıhhat düşüncesinin merkezine yerleştiren kabul benimsendiğinde ise bu rakam 103'e çıkmaktadır ki bu da yaklaşık olarak müttehem râvilerden yarısının rivayetlerinin güvenilir kabul edileceğini gösteren bir önceki grafikle örtüşmektedir. Şiîlikle müttehem râvilerin rivayetlerini nakletmede tek kalan müellifler incelendiğinde ise 19 râvi ile İbn Mâce’nin (ö. 273/887), 15 râvi ile Tirmizînin (ö. 279/892) ve 11 râvi ile de Nesâînin (ö. 303/915) öne çıktıkları görülmektedir. Buhârî ile Müslim ise sadece 2'şer Şî̂likle müttehem râvinin rivayetlerine eserlerinde tek başına yer vermekle diğer eserlerden ayrilırlar.

eğilimin net bir yansıması ise İbn Hacer’ in Hedyüss-sârîsinde takip edilebilir.

21 Buhârî: B, Müslim: M, Ebû Davud: D, Tirmizî: T, Nesâ̂i: N, İbn Mâce: İM. "K-...” rumuzu ilgili müellif dışında Kütüb-i Sitte müelliflerinin tamamının o râvinin rivayetine yer verdiğini gösterdir. " $4 S$ ” rumuzu ise "Dört Sünen" anlamındadır. 
Konu biraz daha daraltılarak farklı oranlarda Şiî eğilimler taşıdığı tespit edilen râvilerin güvenilirlik durumları ve onların rivayetlerine eserlerinde yer veren müellifler incelendiğinde ise konu daha da netleşmektedir. Konuyla ilgili olarak art arda iki grafik verildikten sonra birtakım değerlendirmelere gitmek uygun olacaktır.

Grafik 7. Şiî Eğilimli Râvilerin Güvenilirlik Durumları

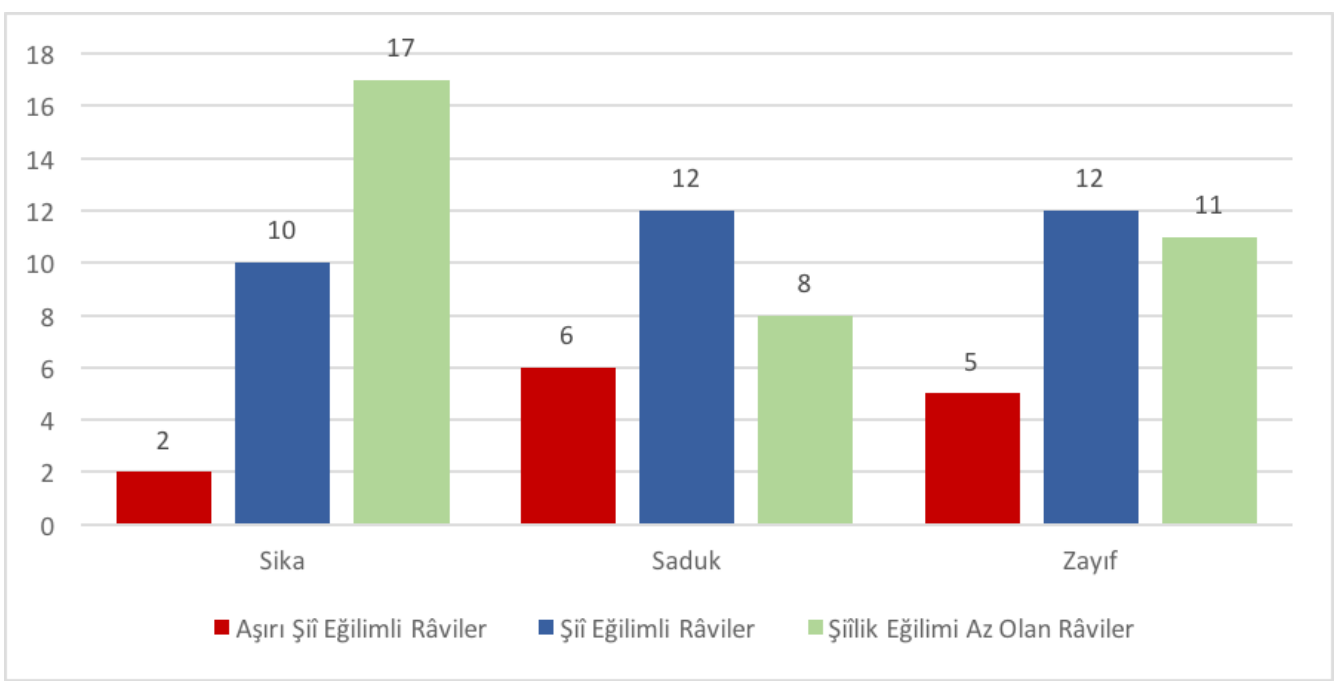

Grafik 8. Şiî Eğilimli Râvilerin Kütüb-i Sitte’deki Durumları

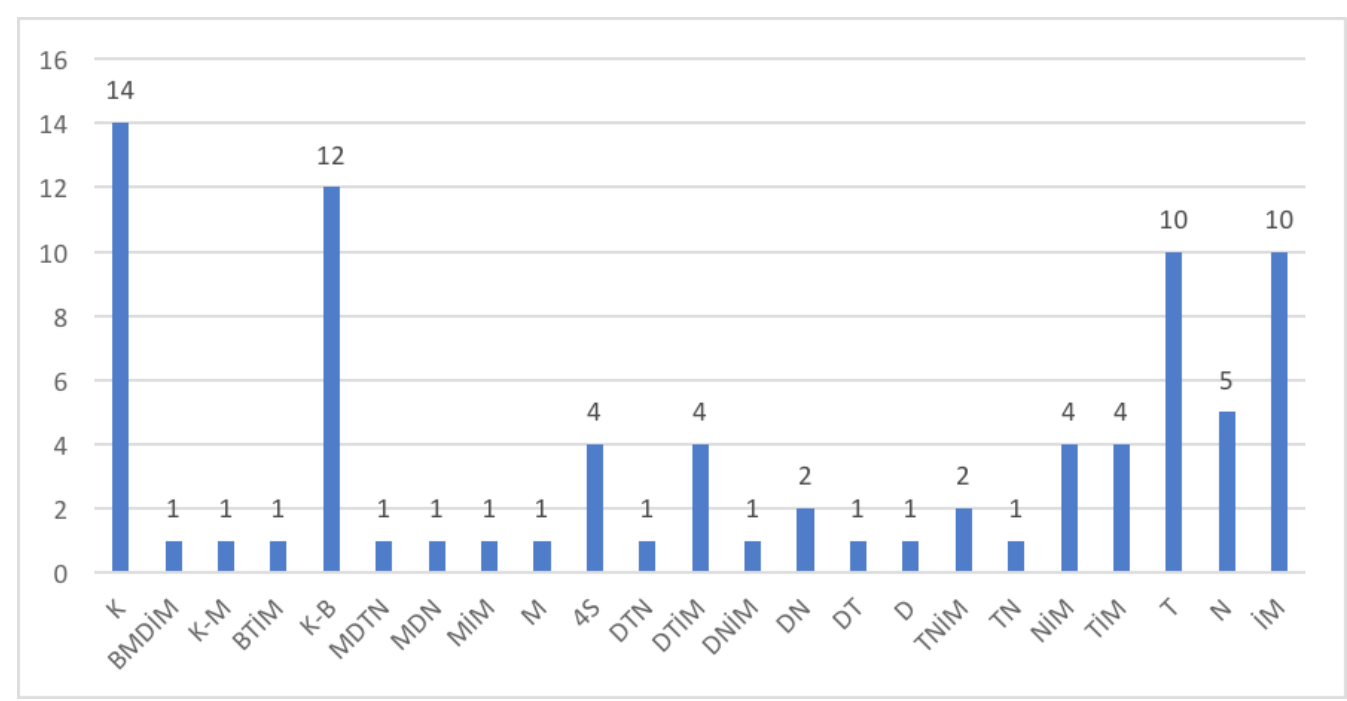


Grafik 8 ve 9'da görüldüğü üzere Şiî eğilimli 83 râvinin 29’u sika, 26’sı saduk, 28'i ise zayıftır. Bu durum zayıflıkla Şiî eğilimler arasında mutlak bir uyum olmadığını göstermektedir. Anlaşıldığı kadarıyla muhaddisler râvinin herhangi bir fırka ile irtibatından ziyade hadis ilminde ehil olup olmadığını dikkate almışlardır. Dikkat çekilmesi gereken bir diğer nokta sika ve zayıf grubunda yer alan râvilerin sayılarıdır. Nitekim sika grubuna giren 29 râviden 17’sinin Şiî eğilimleri zayıf, 10’u Şiî eğilimli iken sadece 2'si aşırı Şiî eğilimlidir. Zayıf grubuna giren râvilerin ise 11'inin Şiî eğilimleri zayıf, 12'si Şiî eğilimli iken 5'i ise aşırı Şiî eğilimlidir. Bu sayısal veriler aşırı Şiî eğilimlerle zayıflık arasındaki ilginin, diğer kategorilerden fazla olduğunu ortaya koymaktadır. Bu râvilerin gerçekten aşırı Şiî eğilimlerinden dolayı mı yoksa hadis zabtındaki problemlerinden dolayı $\mathrm{mı}$ zayıflıkla daha ileri düzeyde ilişkilendirildikleri ise ayrıca araştırılmalıdır.

İlgili râvilere Kütüb-i Sitte müelliflerinin yer verme oranları da özel olarak incelenmeyi hak etmektedir. Kütüb-i Sitte müelliflerinin tamamının rivayetlerini tahric ettikleri râvi sayısı 14’tür. Buhârî ile Müslim sıhhat düşüncesinin merkezine yerleștirildiğinde ise 83 râviden 33'ünün rivayetlerine Buhârî veya Müslim tarafından ya da onların bir veya ikisinin yer aldığı bir grup Kütüb-i Sitte müellifi tarafından yer verildiği görülmektedir. Şiî eğilimli râvilerin rivayetlerine Kütüb-i Sitte içerisinde tek başına yer veren müelliflere yoğunlaşıldığında ise Tirmizî ve İbn Mâce, 10’ar râvi ile öne çıkmaktadır. Öte yandan Şiî eğilimli râvi kümesinin söz konusu eserlerdeki rivayetlerinin fezâil konuları ile daha fazla irtibatlı olduğu da belirtilmelidir. Son olarak başta Buhârî ve Müslim olmak üzere Kütüb-i Sitte müelliflerinin farklı düzeylerde Şî̀ eğilimler taşıyan râvilerin haberlerini, farklı gerekçelerle de olsa tahrîc etmeleri Ehl-i bid'at'ten hadis rivayeti meselesinin usûl metinlerinde çizilen teorik çerçevesi ile rivayet literatüründeki pratik durumu arasında ciddi bir farklılığın olduğunu göstermektedir.

\section{Münekkitler}

Bu başlık altında Şî̀ eğilimli râvileri itham eden kimselerin dönemleri incelenecektir. Münekkitlerin yoğun olarak hangi dönemden itibaren Şiî eğilimli râvileri tespite önem verdikleri hem ekoller arasındaki ayrışmanın derinleşme dönemlerini hem de bu dönemde ilgili tarzda cerh-tađdîl faaliyetinin kimler tarafından icra edildiğini görme imkanı verecektir. Şiîlik ithamında bulunan sıradan isimlerin ya da münekkitlerin dönemlerinin belirlendiği ilk grafikte en erken itham lafzının sahibinin vefatı grafiğe yansıtılmıştır. Ayrıca itham geç tarihli bir eserde yer alsa da, ilgili eserde değerlendirmenin kendisine nispet edildiği kimsenin vefat dönemi dikkate alınmıştır. 11. grafik ise, itham eden ve edilen kimselerin vefat dönemlerini bir arada vererek, ithamların yoğun olarak eleştirilen râvinin çağdaşlarının intibalarından mı kaynaklandığını, hoca-talebe ilişkileri neticesinde elde edilen cerh-ta‘dîl bilgilerinin mi sunulduğunu yoksa ithamlarda yoğun olarak rivayetlerin mi dikkate alındığını tartışmayı hedeflemektedir. 
Grafik 9. Şî̂lik İthamında Bulunan Münekkitlerin Dönemleri

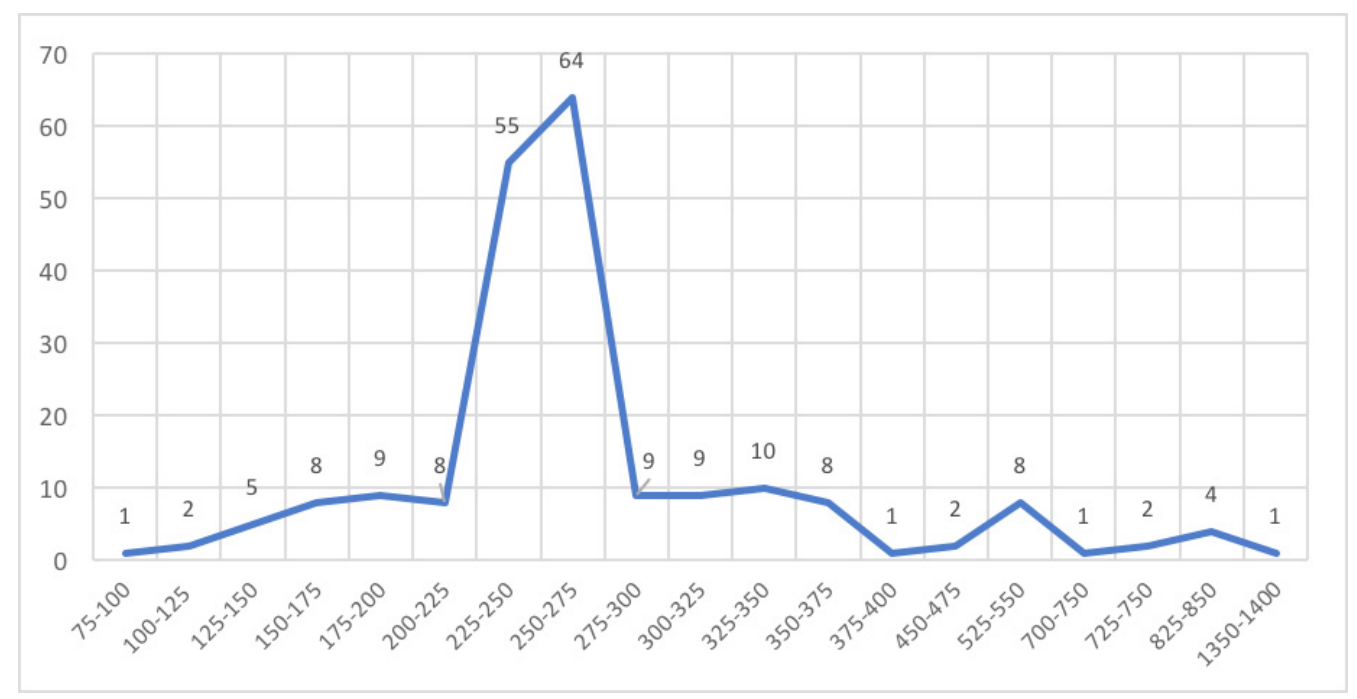

Dikkat çekici bir şekilde herhangi bir râvinin Şiî eğilimlere sahip olduğunu dile getiren müelliflerin sayısının hicrî 225-250 seneleri arasında oldukça ciddi biçimde arttığı ve bu artışın 250-275 seneleri arasında da devam ettiği görülmektedir. Hicrî 225-250 seneleri arasındaki öne çıkan münekkitler rahatlıkla tahmin edileceği üzere her biri de ilmî faaliyetlerini devrin başkenti Bağdat’ta sürdüren İbn Sa'd (16), Yahya b. Maîn (18) ve Ahmed b. Hanbel'dir (9). Ali b. el-Medînî (ö. 234/848-9) ve Buhârî gibi münekkitlerin değerlendirmeleri ise hayli azdır. İlgili dönemde Ehl-i hadîs’ in önce pek çok sıkıntıya maruz kaldığı, sonrasında ise siyaseten daha rahat bir çalışma zemini bulup yeni tarzlarda eser ürettiği bilinmektedir. $\mathrm{Bu}$ dönem aynı zamanda, yukarıda işaret edildiği üzere, Şiî cemaatlerin Sünnî halkalardan ayrıştı̆̆ı zaman aralığının hemen sonrasına tekabül etmektedir. Muhtemelen keskinleşen mezhebî bilinçler muhalifleri tanımlama tavrını da kuvvetlendirmiştir. Hicrî 250-275 seneleri arasına gelindiğinde ise en dikkat çekici münekkitler Cûzcânî (ö. 259/873) (10), İclî (ö. 261/875) (16), Ebû Davud (ö. 275/889) (6), İbn Kuteybe (ö. 276/890) (16) ve Ebû Hâtim’dir (ö. 277/890) (9). Söz konusu isimlerin Ehl-i hadîs düşüncesini ileri derece benimsedikleri ve bazılarının mezhebî taassupları nedeniyle Şî̂ düşüncelere oldukça mesafeli oldukları bilinmektedir.

Hicrî 225-275 seneleri arasındaki münekkitlerin eserleri incelendiğinde onların değerlendirmelerinde neredeyse her zaman kendi kanaatlerini arz ettikleri ve kendilerinden önceki bir münekkide nadiren atıf yaptıkları görülmektedir. Kanaatimizce bu durum onların büyük oranda ilgili râvileri rivayetleri üzerinden değerlendirdiklerine delâlet etmektedir. $\mathrm{Bu}$ dönemin ardından ise ithamlarda ciddi bir düşüş yaşanmıştır. Bu durumun en muhtemel sebebi söz konusu münekkitlerin değerlendirmelerinin sonraki müelliflerce yeterli 
görülmesidir. Nitekim hicrî 300-375 seneleri arasındaki ithamlar büyük oranda Ukaylî (ö. 322/934), İbn Hibbân (ö. 354/965) ve İbn Adîden (ö. 365/976) gelir. Cerh-ta‘dîl sahasında ve özellikle de duafâ türünde eserler kaleme alan bu münekkitlerin eserlerinde, erken devir cerh-taddîl pratiği ile örtüşür bir şekilde rivayetten hareketle râviyi tenkit etme tavrının yanı sıra hicrî 200-250 seneleri arasında yaşamış münekkitlerin değerlendirmelerine de yoğun olarak yer verildiği görülür. ${ }^{22}$ Münekkitleri, dönemlerinin ardından itham eden ve edilen isimleri aynı grafikte görmek erken dönem cerh-ta'dîl pratiğini anlamak açısından hayli faydalı olacaktır.

Grafik 10. Şî̂lik İthamında Bulunan Münekkitlerin ve Şiî Eğilimli Râvilerin Dönemleri

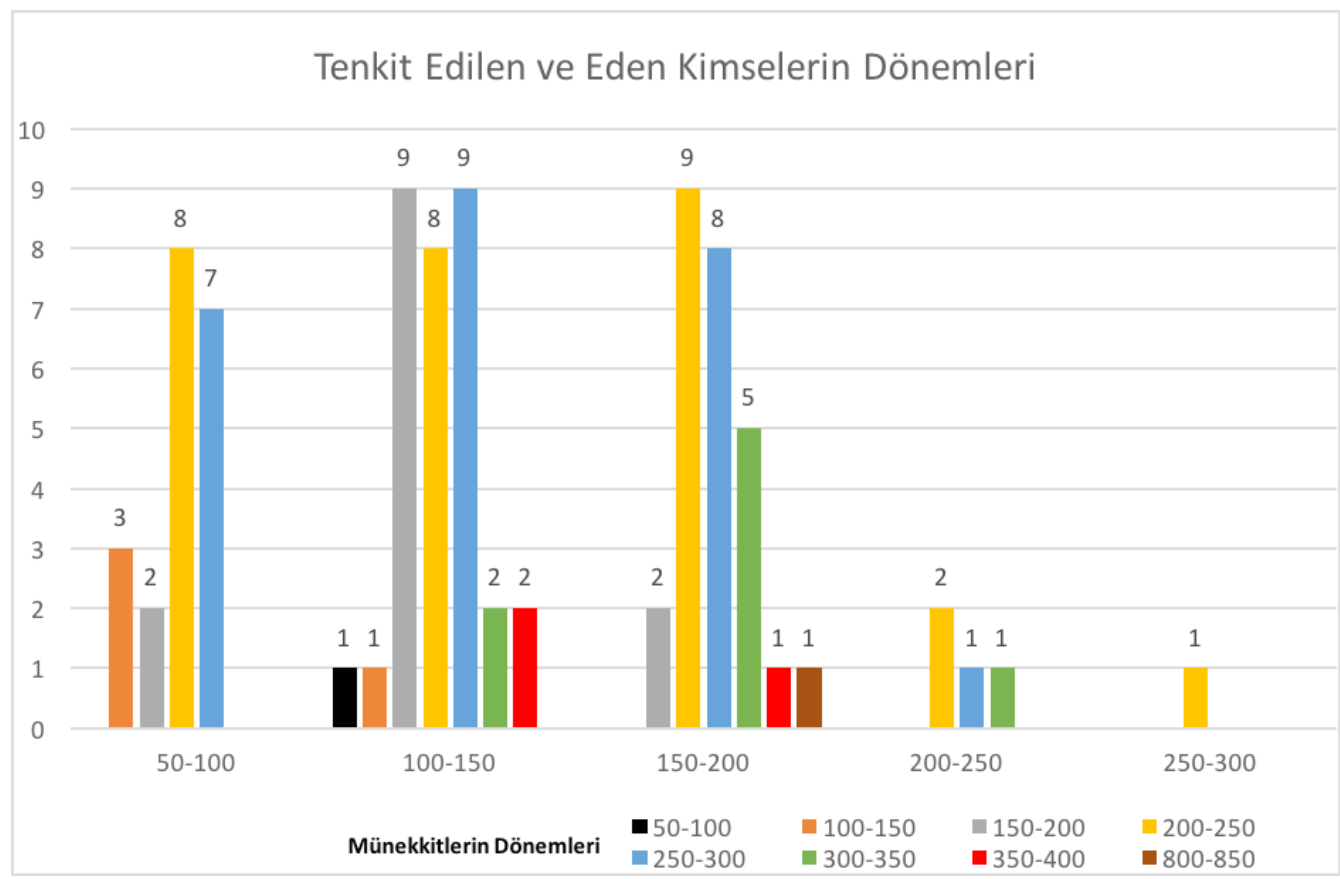

Hicrî 50-100 seneleri arasında yaşayan Şiî eğilimli râviler (20) grafikten anlaşılacağı üzere büyük oranda (15) hicrî 200-300 seneleri arasında vefat eden münekkitlerce tenkit edilmişlerdir. Dolayısıyla ilgili ithamların birebir intibalardan kaynaklanması tarihî olarak mümkün değildir. Bu durumda sistematik olarak cerh-taddîl ilmiyle uğraşan isimlerin ya hoca-talebe ilişkileri ile bu bilgileri aldıkları düşünülecek ya râviler hakkındaki kanaatlerin herkes tarafından her dönemde bilinecek oranda yaygın olduğu söylenecek ya da ilgili râvilerin rivayetleri üzerinden tahlil edildikleri kabul edilecektir. Bu dönem münekkitlerinin bilgi kaynaklarını genellikle zikretmemeleri, onların belki de her bir râviyi yeniden ve

22 İlgili eserlerin etraflı bir tasvir ve tahlili için bk. Mustafa Macit Karagözoğlu, Zayıf Râviler: Duafâ Literatürü ve Zayıf Rivayetler, İstanbul: İFAV, 2014, s. 84-137. 
rivayetleri üzerinden değerlendirdiklerine işaret ediyor olsa gerektir. Zira her bir râvi hakkındaki yargının yaygın bir şekilde bilinmesi de bilgi kaynağını neredeyse hiçbir zaman zikretmemek de pek mümkün görünmemektedir. Tam olarak örtüşmese de benzeri bir durum hicrî 100-150 seneleri arasında vefat eden râviler için de geçerlidir. Zira bu dönemde Şiî eğilimler taşıdığı tespit edilen râvilerin 17'si kendilerini görmeleri, tanımaları tarihi açıdan mümkün olmayan hicrî 200-300 arasında vefat eden münekkitlerce tenkit edilmişlerdir. Ancak tamamının bizzat râviyi tanıyarak yapıldığı söylenemese de hicrî 150-200 seneleri arasında vefat eden 9 münekkidin varlığı dikkat çekicidir. Hicrî 150-200 seneleri arasında vefat eden Şiî eğilimli râviler yine büyük oranda hicrî 200-250 (9) ve 250-300 (8) seneleri arasında vefat eden münekkitlerin tenkidine uğramışlardır. Hem hicrî 250-300 hem de 300-350 (5) seneleri arasında vefat eden münekkitlerin bu dönem râvilerini birebir tanışıklıklarla itham etmeleri mümkün değildir. Bu durumda ilgili ithamlar ya metinler üzerinden ya da hoca-talebe ilişkisi ile alınan bilgilerle dile getirilmiş olmalıdır. Hicrî 200-250 seneleri arasında vefat eden münekkitlere daha yakından bakıldığında ise bu dönemde de çoğu tenkidin şahsi intibalardan kaynaklanmasının düşük bir ihtimal olduğu anlaşılır. Zira hicrî 150-175 arasında vefat eden Şiî eğilimli râvilerin 4'ünün münekkidi 250-275 seneleri arasında vefat etmiştir. Hicrî 175-200 vefatlı râvilerin ise 3’ü hicrî 250'den sonra vefat eden münekkitlerce tenkit edilmiştir.

Grafik ve yukarıda söylenenler hakkında genel bir değerlendirme yapmak gerekmektedir. Öncelikle bu veriler râvilerin Şiîlik eğilimini tespit eden münekkitlerin genellikle bu râvileri bizzat görmeden bu ithamı yaptıklarını gösterir. Bu durum hem cerh-tadîl bilgisinin intikali sorunsalı hem de cerh-tadîl pratiğinin nasıl işletildiği hakkında ciddi çıkarımlar yapmaya imkan verir. Yukarıda belirtildiği üzere söz konusu müelliflerin bilgi kaynaklarını genellikle anmadıkları dikkate alınınca ya bu isimlerin kendilerinden önceki nesilden aldıkları cerh-ta'dîl bilgilerini bilgi kaynaklarını zikretmeden kullandıkları ya bu bilgilerin kaynağa ihtiyaç bırakmayacak şekilde maruf olduğu ya da münekkitlerin her bir râvi için bir yargıya vardıkları söylenmek durumundadır. Kanaatimizce üst nesil bilgi kaynaklarının kasitlı ve muttarit olarak zikredilmemesi pek olası değildir. Kaldı ki hicrî 225-250 arasında vefat eden münekkitler, Vekî b. el-Cerrâh (ö. 197/812), Yahya b. Saîd el-Kattân (ö. 198/813), Abdurrahman b. Mehdî (ö. 198/813-4) gibi üst nesil hocalarının râvilere dair kanaatlerini nadir de olsa zikrederler. Bu tarz bilgilerin kaynağa ihtiyaç bırakmayacak oranda yaygın olmadığı da ehlinin malumudur. Bizzat görüşülmesi mümkün olmayan bir râvi hakkında yargıya varmanın yolu ise, eğer bilgi üst nesilden gelmiyorsa, o râvinin rivayetlerini incelemek ve rivayetleri üzerinden bir yargıya varmaktır. Râvinin zabtını tespit etmenin neredeyse yegane yolu olan râvinin rivayetlerini bir araya getirip diğer râvilerin naklettikleriyle karşılaştırmayı ifade eden muâraza/mukâbele yöntemi, muhtemelen râvilerin adaletini tespitte de yoğun olarak işletilmiştir. Her bir râviyi rivayetleri çerçevesinde yeniden değerlendirme olgusu, normal şartlarda cerh-tádîl bilgilerini üst nesilden hoca-talebe ilişkisi ile almaları ve yorumlarının üst nesil ile büyük oranda uyuşması beklenen münekkitlerin, pek çok râvinin 
durumu hakkında hocalarından farklılaşan kanaatler serdetmelerinin en temel sebebidir. ${ }^{23}$ Öte yandan grafikteki bütün veriler Ahmed b. Hanbel ve tabakasındaki münekkitlerin cerhtádîl ilminin nihai halini almasındaki tartışılmaz rollerine de işaret etmektedir. Burada bir diğer problem ise ilgili râviler hakkındaki ithamların hangi lafızlarla yapıldığıdır.

\section{Tenkit Lafızları}

Makalenin girişinde ifade edildiği üzere farklı düzeylerde Şiî eğilimlere nispet edilen râviler Şîa kelimesi ve bu kelimeden türetilen çeşitli ifadelerin yanı sıra Râfizî, Sebeî, Gâlî, Muhtârî, Haşebî, Alevî vb. kelime ve kavramlarla da itham edilmişlerdir. Bu itham lafızları ilk olarak itham sahiplerinin kullanımlarını (12. grafik), ikinci olarak ise (13. grafik) itham edilen râvilerin nitelendikleri kavramları görecek şekilde dönemsel olarak grafiğe dökülecektir. Böylece tenkit lafızlarının gelişimi ve yoğunlaştığı zaman aralığı tespit edilmeye çalışlacaktır.

23 Halil İbrahim Turhan ricâl ilminin serüvenini cerh-ta‘dîlin yapılma tarzı yerine tarihî süreklilikte takip etmeye çalıştığı için üst nesil münekkitlerle talebeleri arasındaki ihtilafların sebepleri onun emek mahsulü eserinde tam olarak netleşmez (bk. Ricâl Tenkidinin Doğuşu ve Gelişimi (Hicrî İlk İki Asır), İstanbul: İFAV, 2015). 
Grafik 11. İtham Lafızları (münekkitler ve dönemleri)

\begin{tabular}{|c|c|c|c|}
\hline ก่욤 & Şiî ve türevleri & 1 & \\
\hline & Şiî ve türevleri & 1 & \\
\hline & Alevî & 1 & \\
\hline 点 & Şiîve türevleri & 1 & \\
\hline$\underset{\pi}{\sim}$ & Râfizî & 1 & \\
\hline & Şiî ve türevleri & 3 & \\
\hline$\underset{7}{7}$ & Râfizî & 1 & \\
\hline 육 & Hakaret ederdi, Râfizî & 1 & \\
\hline & Hakaret ederdi & 1 & \\
\hline & Şiî ve türevleri & 2 & \\
\hline 음 & Recat, Haşebî & 1 & \\
\hline in & Muhtârî & 2 & \\
\hline-1 & Haşebî & 1 & \\
\hline & Alevî & 1 & \\
\hline$\stackrel{\sim}{N}$ & Şiî ve türevleri & 2 & \\
\hline D & Recat, Râfizî & 1 & \\
\hline & Şiî ve türevleri & & 16 \\
\hline & Sebeî, Râfizî, recat & 1 & \\
\hline 윤 & Recat & 1 & \\
\hline ஸे & Râfizî & 2 & \\
\hline & Muhtârî, Râfizî & 1 & \\
\hline & Haşebî & 1 & \\
\hline & Hakaret ederdi, Râfizî & 3 & \\
\hline & Şiî ve türevleri & & 15 \\
\hline & kötü mezhep & & \\
\hline ก & isyana katılmak & 1 & \\
\hline ஸ่ & Hz. Ali'nin şurtasından & 1 & \\
\hline$N$ & haktan sapmış & 1 & \\
\hline & Hakaret ederdi, Râfizî & 2 & \\
\hline & Alevî & 1 & \\
\hline$\stackrel{n}{\stackrel{n}{N}}$ : & Şiî ve türevleri & 2 & \\
\hline & Şiîve türevleri & 3 & \\
\hline & Râfizî & 2 & \\
\hline & Şiî ve türevleri & 2 & \\
\hline & Râfizî & 1 & \\
\hline 空, $\stackrel{n}{n}$ & Şiîve türevleri & 3 & \\
\hline$\underset{\infty}{\tilde{N}}, \stackrel{0}{\infty}$ & Şiîve türevleri & 1 & \\
\hline
\end{tabular}

Grafik 12. İtham Lafızları (râviler ve dönemleri)

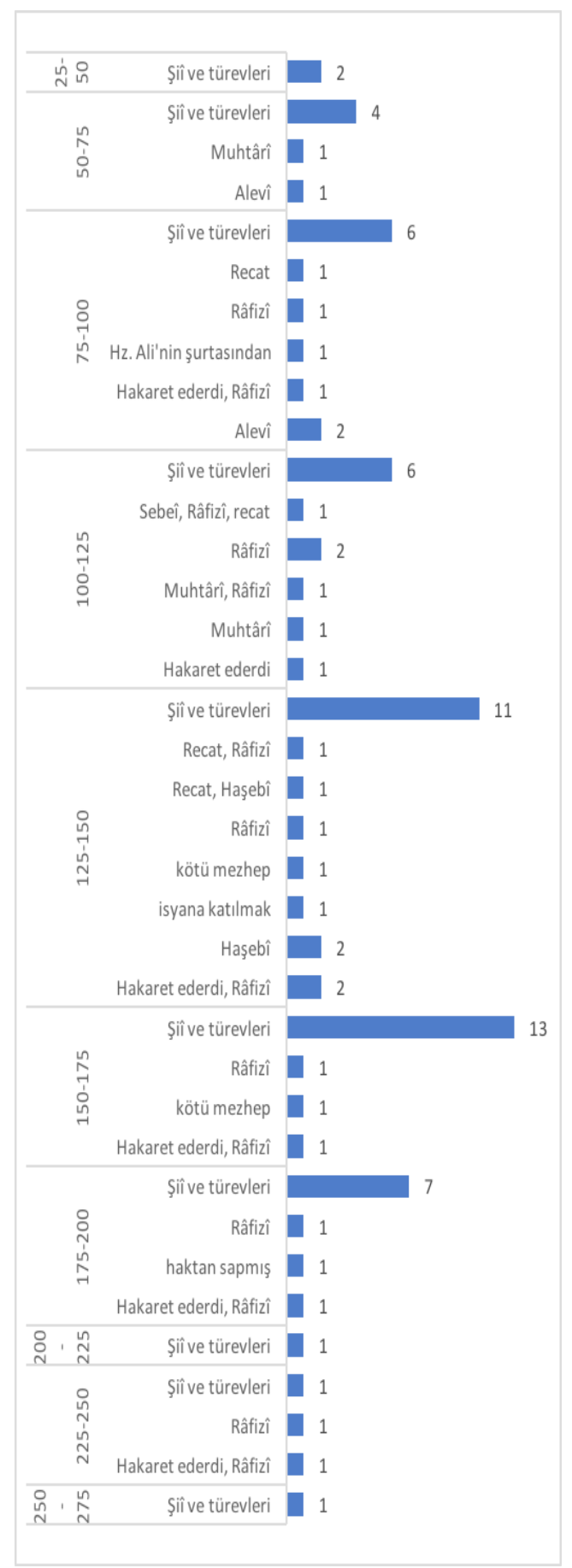


Münekkitlerin bir râviyi Şî̂ düşüncelerle irtibatlandırırken hangi lafızları hangi dönemde kullandıkları incelendiğinde her dönemde en çok karşılaşılan itham lafzının Şîa kelimesi ve türevleri etrafında şekillenen kavramlar olduğu görülür. Hicrî 75-225 seneleri arasında Râfizî kavramı çok fazla kullanılmazken (5), Haşebî, Muhtârî, Alevî, hakaret etme, recate inanma gibi farklı lafızlara yer verilmiştir. Dolayısıyla bu dönemdeki itham lafızlarının çeşitlilik arz ettiği söylenebilir. Hicrî 225-250 seneleri arasında münekkitler genellikle Şîa kelimesi etrafında şekillenen kavramları kullanmışlardır (16). Bu durum sistematik anlamda cerh-tádîl ile uğraşan âlimlerin lafız tercihinin bu yönde olduğu anlamına gelir. Sonraki dönemlerde ise kötü bir mezhebi kabule sahip olmak, haktan sapmak, Ehl-i beyt temelli bir isyana katılmak gibi kavram ve tasvirler de ilgili lafızlara eklenmiştir. Ashâba/selefe hakaret ettiği kaydedilen râvilerin aynı zamanda Râfizî olarak da nitelenmiş olmaları dikkat çekici bir durumdur. Konuya daha yakından bakıldığında erken literatürde sadece ashâba hakaret ettiği belirtilen râvilerin geç literatürde genellikle Râfizî olarak anıldıkları görülür. Bu durum ashâba hakaret olgusu ile Râfizî olmak arasında kuvvetli bir ilgi olduğunu düşündürür.

Şiî eğilimli râvilerin itham edildikleri lafızlar onların vefatlarına göre belli bir kronolojiye oturtulduğunda ise lafızların tarihi seyri hakkında ciddi bilgiler edinilebilmektedir. Örneğin Alevî lafzı her üçü de hicrî 1. asırda yaşayan 3 râvi için kullanılmıştır. Büyük oranda Ali yanlısı olmak, tafdil tartışmalarında onu Hz. Osman’a öncelemek anlamında kullanılan bu lafız sonraki dönemlerde terk edilmiştir. Recate inanma ithamı (4), hicrî 75-150 seneleri arasında vefat eden râvilere yöneltilmiştir. Bu durum söz konusu inanışın marjinal Şî̂ cemaat yapılarında bu tarihlerde ortaya çıtığını gösterir. Daha geç literatürde ise bu inanışın dinî kaynakları üzerinde ciddi bir şekilde duran Şiî müelliflerin gayretleri sayesinde recat düşüncesi müesses Şiîlikte de kendisine yer bulmuştur. Muhtârî ifadesinin de hicrî 50125 seneleri arasında vefat eden râviler için kullanılması gayet tabiidir. Zira söz konusu tarih aralı̆̆ından sonra vefat eden bir ismin Muhtâr b. Ubeyd es-Sekafînnin (ö. 67/687) taraftarı olması mümkün değildir. Buna rağmen aynı isim bağlamında gündeme gelen Haşebî kavramının (3) en azından bir kullanımının hicrî 153'te vefat eden bir isim hakkında olması, ilgili kavramın her zaman doğru bir tarihi zeminde anılmadığını göstermektedir. Bu grafikte de Şiî ve kelimesi ve türevlerinin her dönemdeki râviler için sıklıkla istimal edildiği açıktır. Ashâb hakkında olumsuz ifadeler kullanma tavrı da anlaşılacağı üzere belirli bir döneme hasredilememektedir. Nitekim erken dönemden itibaren ashâb hakkında dile getirilen olumsuz nitelemeler ya da onların meâyib/mesâlibine dair rivayetlerin dile getirilmesi, daha sonraları mesâlib literatürünün doğuşuna da zemin hazırlamıştır.

\section{Değerlendirme ve Sonuç}

Hicrî ilk üç asırdaki Şiî eğilimli olan veya olmakla itham edilen râvi kümesi farklı açılardan incelendiğinde Sünnî-Şiî ders halkalarının ayrışma dönemi, iki ekol arasındaki rivayet geçişkenliklerinin zamanı, Ehl-i bid'at'ten hadis rivayeti ve Ehl-i hadîs münekkitlerinin bir râvi hakkında yargıya varırken ne tür bir metot izlediklerine dair birtakım yargılara varma imkanı 
vermektedir. Anlaşıldığ kadarıyla hicrî 2. asır hala pek çok açıdan çalışılmaya muhtaçtır. Zira hem Ehl-i hadîs ve Şî̀ cemaatlerin kimlik bulma süreci hem de cerh-tádîl ilminin sistematik bir zemine kavuşması hicrî 2. asrın ilk çeyreğinden sonra söz konusu olmuştur. Sünnî ve Şiî halkalar ise sınırlı bilgi akışlarının olduğu hicrî 4. asrın başları ya da bir başka deyişle Şiî görüşleri destekleme ihtimalinden ötürü mevzii olarak Şiî kaynaklara aktarılan Sünnî rivayetler istisna edilecek olursa bir daha asla birleşmemek üzere bu dönemde ayrışmıslardır. Nitekim hicrî 3. asırdan sonra Şiî eğilimli veya müttehem râvilere Sünnî eserlerde çok fazla tesadüf edilmemesinin nedeni budur. Yine anlaşıldığı kadarıly hicrî 2. asırda Ehl-i bid'at’ten hadis rivayeti pratikte sorun olarak görülmemektedir. Bu dönemde Mâlik b. Enes (ö. 179/795), Yahya b. Saîd el-Kattân (ö. 198/813) gibi bazı isimler istisna edilecek olursa sadece güvenilir râvilerin rivayetlerini almayı hem teoride hem de pratikte prensip olarak benimseyen muhaddis yok gibidir. Aynı tavrın hadisin sıhhat şartları netleşmesine ve shhhat merkezli metinlerin derlenmesine rağmen hicrî 3. asırda da sürdürülmesi, klasik hadis usûlünde tasvir edildiği şekliyle Ehl-i bid'at'ten hadis rivayeti meselesinin yeniden ele alınması gerektiğini göstermektedir. Son olarak cerh-tádîlin icra edilme tarzı da yeniden etraflıca düşünülmelidir. Münekkit âlimlerin değerlendirmelerinin hesabı verilmemiş şahsî görüşlere değil, muâraza ya da mukâbele olarak anılan bir râvi değerlendirme metoduna istinat ettiği gerçeği onların râviler hakkında ileri derecede yakın yargılara varmalarından anlaşılmaktadır. ${ }^{24}$ Burada varılan sonuçlar münekkitlerin genellikle tarihen kendileri ile görüşmeleri mümkün olmayan râvileri adaletle ilişkili bir konu hakkında değerlendirdiklerini tespit etmektedir. Bu durumda râvi hakkındaki bilgiler ya üst nesil hocalardan alınmış olmalıdır ya da râvilerin durumu ekstra bir atfa ihtiyaç duyulmayacak şekilde bilinmektedir. Ancak her iki ihtimal de, yukarıda ifade edildiği üzere farklı açılardan tartışmaya açıktır. En makul çözüm ise münekkit bilginlerin tıpkı râvinin zabtını, onun naklettiği metinler üzerinden tespit ettikleri gibi adaletini de büyük oranda rivayetler üzerinden belirlemiş olmalarıdır. Anlaşıldığı kadarıyla Hz. Ali ya da Ehl-i beyt hakkında ileri düzeyde zayıf bir fezâil rivayetini ya da ashâb hakkında tezyif içerikli haberleri nakleden râviler Şîilik ithamına maruz kalmıştır. Burada Şîillikle müttehem ya da Şiî eğilimli râviler çerçevesinde dile getirilen iddianın kezzâb kabul edilen ya da farklı mezhebî yapılarla ilişkilendirilen râvilere teşmil edilmesi de mümkündür.

Sonuç olarak şu hususun altı çizilmelidir: Ricâl kitaplarındaki statik bilgilerin hadis tarihi açısından anlamlı kılınabilmesi ancak bu kitaplara yönelik tematik yaklaşımlarla mümkün olabilecektir. Burada gösterilmeye çalışıldığı üzere belli bir tema etrafında anılan râvilerin durumlarının farklı açılardan tahlil edilmesi sadece o râvilere ilişkin çıkarımlar yapılmasına değil hadis tarihinin kapalı kalan dönemleri ve tartışma konularına dair de birtakım fikirler yürütülmesine imkan verecektir.

24 Henüz tamamlanmayan bir çalışmadan öğrendiğimiz kadarıyla Ahmed b. Hanbel ve Yahya b. Maîn’in cerh-tádîle dair değerlendirmelerini derleyen Mevsûa'larındaki ittifak oran \% 95 civarındadır. Scott C. Lucas’ın örneklemi de İbn Sa‘d, Ahmed b. Hanbel ve Yahya b. Maîn’in değerlendirmeleri arasında oldukça yüksek oranda ittifak olduğunu gösterir (Constructive Critics, Hadith Literature and the Articulation of Sunnī Islam: The Legacy of Generation of İbn Sa'd, İbn Ma'ìn, and İbn Hanbal. Leiden: E.J. Brill, 2004, s. 310-4). 


\section{Kaynaklar}

Azîzî, Hüseyin - Pervez Rüstegâr - Yusuf Bayât. Râviyân-i müşterek: pejûjeşî der bâzşinâsî-i râviyân-i müşterek-i Şîa ve Ehl-i sünne. Kum: Bustân-i Kitâb, 1380, trc. er-Ruvâtüll-müşterekûn beyneşs-Şia ve'sSünne. I-II, Tahran: el-Mecma'u’l-Alamî li'l-Takrîb Beyne'l-Mezâhibi'l-İslâmiyye, 1430/2009.

Buckley, Ron P.. "Ja'far al-Sādiq as a Source of Shīī Traditions.” The Islamic Quarterly, 1999, XLIII, sy. 1, s. 37-58 (Makale Türkçe’ye tercüme edilmiştir, bk. "Şiî Hadislerin Kaynağı Olarak Cáfer es-Sâdık." Şî̀nın Hadis Anlayışı Üzerine İncelemeler [der. ve trc. M. Macit Karagözoğlu - M. Enes Topgül]. İstanbul 2015, s. 41-65).

Dann, Michael. Contested Boundaries: The Reception of Shī ite Narrators in the Sunnī Hadith Tradition (doktora tezi, 2015). Princeton University.

Fayda, Mustafa. "Hemdân (Benî Hemdân).” DİA. XVII, 179-180.

Haider, Najam. The Origins of the Shī 'a: Identity, Ritual, and Sacred Space in Eighth-Century Küfa. Cambridge: Cambridge University Press, 2011.

İbn Hacer, Ahmed b. Ali es-Askalânî. Tehzîbü’t-Tehzîb (nşr. Halîl Me’mûn Şîha - Ömer Selâmî - Ali b. Mes'ûd). I-VI, Beyrut: Dâru'l-Márife, 1416/1996.

İbnü'l-Vezîr el-Yemânî, Muhammed b. İbrahim. el-Avâsım ve'l-kavâsım fi'z-zeb an sünneti Ebi'l-Kâsım (nşr. Şuayb el-Arnaût). I-IX, Beyrut: Müessessetü’r-Risâle, 1412/1992.

Kallek, Cengiz. "Esed (Benî Esed).” DİA. XI, 363-5.

Karagözoğlu, Mustafa Macit. Zayıf Râviler: Duafâ Literatürü ve Zayıf Rivayetler, İstanbul: İFAV, 2014.

el-Kâsımî, Muhammed Cemâleddin. Kavâidü't-tahdîs min funûni mustalahi'l-hadîs (nşr. Muhammed Behcet el-Baytâr). Dımaşk: Mektebü’n-Neşri'l-Arabî, 1343/1925.

el-Keşşî, Muhammed b. Ömer. İhtiyâru Márifeti’r-ricâl (nşr. Hasan el-Mustafavî). Meşhed: Dânişkâh-i Meşhed, 1348hş./1969.

Kuzudişli, Bekir. Şîa ve Hadis: Başlangıcından Kütüb-i Erbaa'ya Hadis Rivayeti ve İsnad. İstanbul: Klasik, 2017.

------. "Sunnì-Shì' ì Interaction in the Early Period: The Transition of the Chains of Ahl al-sunna to the Shī'a." Ilahiyat Studies, 2015, VI, sy. 1, s. 7-45.

Lalani, Arzina R.. Early Shī̄i Thought: The Teachings of Imam Muhammad al-Bāqir, London: I.B. Taurus, 2000.

Lucas, C. Scott. Constructive Critics, Hadìth Literature and the Articulation of Sunnī Islam: The Legacy of Generation of İbn Sa'd, İbn Ma'ìn, and İbn Hanbal. Leiden: E.J. Brill, 2004.

Newman, Andrew. The Formative Period of Twelver Shī'ism: Hadìth as Discourse Between Qum and Baghdad. Richmond: Curzon, 2000.

Sachedina, Abdulaziz A.. "The Significance of Kashshîs Rijāl in Understanding the Early Role of the Shīite Fuqahā.” Logos Islamikos (ed. Roger M. Savory-Dionisius A. Agius), Toronto 1984, s. 183-206. (Makale Türkçeye tercüme edilmiştir, bk. "Şiî Fakihlerin İlk Dönemdeki Rolünün Anlaşılmasında Keşş̂̂nin Ricâl'inin Önemi." Şı̂ảnın Hadis Anlayışı Üzerine İncelemeler [der. ve trc. M. Macit Karagözoğlu-M. Enes Topgül]. İstanbul 2015, s. 67-89).

Topgül, Muhammed Enes. Hadis Râvilerinde Şî̀lik Eğilimi (yüksek lisans tezi, 2010). Marmara Üniversitesi Sosyal Bilimler Enstitüsü.

-------. Erken Dönem Şî̀ Ricâl İlmi: Keş̧̧ิ Örneği. İstanbul: İFAV, 2015.

------. "Bir Cerh Sebebi Olarak Teşeyyu' (Şiîlik Eğilimi) Kavramına Tarihsel Bir Bakış." Marmara Üniversitesi İlahiyat Fakültesi Dergisi. 2012, sy. 42, s. 47-76.

Turhan, Halil İbrahim. Ricâl Tenkidinin Doğuşu ve Gelişimi (Hicrî İlk İki Asır). İstanbul: İFAV, 2015. 